\title{
İşbirlikli Öğrenmeyi Destekleyen Üç-Boyutlu Sanal Öğrenme Ortamı Geliştirilmesi: Bir Durum Çalışması
}

\section{Development of 3D Virtual Learning Environment That Supports Collaborative Learning: A Case Study}

\author{
Bahattin Selim PAMUKCU ${ }^{1}$, Hasan ÇAKIR ${ }^{2}$
}

- Geliş Tarihi: 26.06.2019 • Kabul Tarihi: 31.12.2019 • Çevrimiçi Yayın Tarihi: 31.12 .2019

\section{Öz}

Bu çalışmanın amacı, işbirlikli öğrenmeyi destekleyen üç-boyutlu sanal dünyaları öğrenme ortamı olarak geliştirmek ve geliştirilen bu ortamların kullanımını kolaylaştıran ve engelleyen etkenleri belirleyerek olası kullanımı engelleyici etkenleri ortadan kaldıracak çözümler sunmaktır. Araştırma yöntemi olarak biçimlendirici araştırma kullanılmıştır. Araştırma, Ankara ili içerisinde bulunan bir üniversitenin Bilgisayar ve Öğretim Teknolojileri Öğretmenliği bölümünde 4.sınıfa devam eden 56 katılımcı ile yürütülmüştür. Araştırmanın uygulama aşaması 6 hafta boyunca devam etmiştir. Araştırmanın veri toplama işlemleri, içerisinde açık ve kapalı uçlu sorular yer alan kullanım anketi ve odak grup görüşmeleri ile gerçekleşmiştir. Verilerin analizi aşamasında ise nicel veriler için betimsel istatistik kullanılırken, nitel veriler için ise içerik analizi kullanılmıştır. Araştırmanın sonuçlarına göre işbirlikli öğrenmeyi destekleyen üç-boyutlu sanal öğrenme ortamlarının kullanımına etki eden faktörlerin sosyal bulunuşluk, motivasyon ve kullanımla ilgili bileşenler olduğu görülmüştür.

Anahtar sözcükler: üç-boyutlu sanal öğrenme ortamları, sanal kampüs, işbirliğine dayalı sanal öğrenme ortamları, sosyal bulunuşluk

Atıf:

Pamukcu, B. S., ve Çakır, H. (2020). İşbirlikli öğrenmeyi destekleyen üç-boyutlu sanal öğrenme ortamı geliştirilmesi: bir durum çalışması. Pamukkale Üniversitesi Eğitim Fakültesi Dergisi, 49, 530-563. doi: 10.9779/pauefd.582519

\footnotetext{
* Bu makale, birinci yazarın ikinci yazar danışmanlığında hazırladığı yüksek lisans tezinden üretilmiştir.

1 Doktora Öğrencisi, Gazi Üni. Eğitim Bilimleri Enstitüsü Bilgisayar ve Öğretim Teknolojileri Eğitimi Bil. Dal., selimpamukcu@gmail.com, https://orcid.org/0000-0002-4209-7109

2 Doç. Dr. Öğr. Üyesi, Gazi Üni. Gazi Eğitim Fakültesi Bilgisayar ve Öğretim Teknolojileri Eğitimi Böl., hasanc@gazi.edu.tr, https://orcid.org/0000-0002-4499-9712
} 


\begin{abstract}
The aim of this research is to develop a $3 \mathrm{D}$ virtual learning environment that supports collaborative learning, to identify elements that facilitate and obstruct the use of such environments, and to present solutions for problems which appear during the use of such environments. The method used in this study was formative research. The study was conducted with 56 senior students who were at the time studying in the Computer Education and Instructional Technology department at a university located in Ankara, and the implementation process lasted six weeks. In the data collection process, the study used focus group interviews and usage surveys that consisted of closed and open-ended questions. In the data analysis phase, descriptive statistics and content analysis were used. The results have shown that factors which influence the use of the 3D virtual learning environments that support collaborative learning are the components of social presence, motivation and utilization.
\end{abstract}

Keywords: $3 \mathrm{~d}$ virtual learning environments, virtual campus, collaborative learning in $3 \mathrm{~d}$ virtual environments, social presence

\title{
Cited:
}

Pamukcu, B. S., ve Çakır, H. (2020). Development of 3d virtual learning environment that supports collaborative learning: a case study. Pamukkale Üniversitesi Eğitim Fakültesi Dergisi, 49, 530563. doi: 10.9779/pauefd.582519 


\section{Giriş}

Ülkelerin sürdürülebilir bir kalkınma süreci geçirmesi için birleşmiş milletler sürdürülebilirlik ile ilgili olarak çeşitli hedefler belirlemiştir. 2030'a yönelik olan hedeflerden eğitim ile ilgili olanı kapsayıcı ve adil kalitede eğitim sağlamak ve herkes için yaşam boyu öğrenme firsatlarını teşvik etmektir (United Nations, 2015). Bu bağlamda eğitim kuruluşları tarafından yapılan yorumlardan bazıları kaliteli ve eşit bir eğitim sağlamak için yapılandırmacı öğrenmenin müfredat içerisinde bulunması gerektiği yönündedir (Franczak, 2018). Araştırmalar işbirliğine dayalı öğrenme yöntemiyle gerçekleştirilen yapılandırmacı öğrenmenin etkili ve verimli sonuçlar yarattı̆̆ını göstermiştir (Duffy ve Cunningham, 1996; Zajda, 2018). Duffy ve Cunningham, (1996) bu etkilerin doğru olarak gözlemlenebilmesi için işbirliğine dayalı öğrenme ile ilgili yapılan araştırmalarda dikkat edilmesi gereken değerlerin; grupların cinsiyete göre dağılımı, gruplardaki öğrenen sayısı ve tüm grup üyelerinin sürece katkısının derecesi olarak belirtmiştir. Başka bir deyişle bu yaklaşıma göre iş yükü paylaşımı, akran öğrenimi, sınıf içi etkileşimin artması gibi olumlu sonuçlar ortaya çıkarmıştır. Doğası gereği bu yaklaşım aynı zamanda sosyal-diyalog imkânı sağlayan bir öğrenme süreci olarak da tanımlanmıştır (Duffy ve Cunningham, 1996). Yapılan çalışmalar işbirliğine dayalı öğrenme yaklaşımının kullanılmasının öğrencilerdeki sosyalleşmenin olumlu yönde artmasına da katkı sağladığını göstermiştir (Chen, 2017; Karagiorgi ve Symeou, 2005). İşbirliğine dayalı öğrenmenin internet destekli olarak gerçekleşmesiyle sosyalleşme, etkileşim ve iletişim açısından öğrenmenin daha zengin olduğu sonucu ortaya çıkmıştır (Korucu ve Çakır, 2015; Tan ve Jones, 2008). Aynı zamanda bu teknolojiler katılımcıların motivasyon, memnuniyet, etkileşim, sosyalleşme ve iletişim açısından olumlu sonuçlar almasına da imkan sunmaktadır (Horzum, 2015; Yılmaz, 2017). Elde edilen bu verilerden yola çıkarak yaklaşımın internet teknolojileri kullanılarak gerçekleştirilmesinin olumlu sonuçlar çıkarabileceği düşünülmektedir.

İnternet ve teknoloji desteki gerçekleşen eğitimlerin olumlu etkilerinin yanında bazı sinırlılıkları da bulunmaktadır. Bunlardan biri bu ortamlarda sosyal bulunuşluk algısının düşük olmasıdır (Horzum, 2015; Tu ve McIsaac, 2002). Teknoloji destekli olarak gerçekleştirilen eğitimler de sosyal bulunuşluk algısının oluşturulması her ne kadar zor olsa da, imkânsız olarak düşünülmemektedir (Horzum, 2015; Lowenthal ve Mulder, 2017). Uygulanan teknolojide kullanıcıların sistem içerisindeki etkileşimlerinin doğru olarak gerçekleştirilmesi ile bu algının oluşması sağlanabilmektedir (Garrison, Anderson ve Archer, 1999; Lowenthal ve Mulder, 2017). Bu bağlamda internet ve teknoloji kullanılarak gerçekleştirilen eğitimlerde oluşabilecek sosyal bulunuşluğa bağlı sınırlılıkların işbirliğine dayalı öğrenme ile birlikte kullanılmasıyla Tan ve Jones'in da (2008) belirttiği gibi sosyalleşme, etkileşim ve iletişim açısından daha zengin ortamlar sağlayacağı ve sinırlılıkların azalması yönünde katk1 sağlayabileceği düşünülmektedir. Quest Atlantis, Active Worlds, Second Life, OpenSim, vAcademia vb. üçboyutlu sanal dünyaların işbirliğine dayalı öğrenmelerde kullanılması hem etkililik, hem verimlilik hem de sosyal bulunuşluk açısından olumlu sonuçlar oluşturabileceği düşünülmektedir. Barab, Kling ve Gray’e (2004) göre öğretim ortamı olarak geliştirilebilen bu üç-boyutlu sanal dünyalar, pedagojik ve teknolojik açıdan öğrenmeyi destekleyen yenilikçi ve güçlü sistemler olarak tanımlanmıştır. Genel olarak üç-boyutlu sanal dünyaların eğitim ortamı olarak kullanılması hakkında yapılan araştırmalarda bu ortamların özellikleri şu şekilde 
sıralanmıştır (Dillenbourg, Schneider ve Synteta, 2002; Jones ve Alba, 2019; Rodriguez, Santiago, ve Covarrubias, 2016; Savva, 2016):

- Bilgi ve sosyal alan imkânı

- Katılımcı aktifliği

- Gerçek dünya benzerliği

- Pedagojik ve teknolojik uyum kolaylığ

Kullanıcıların sanal dünyalar içerisinde avatarlarını istediği gibi kontrol edebilmesi, ortam ile etkileşimde bulunabilmesi ve özellikle ses teknolojisinin üç-boyutlu olması, sistem içerisinde gerçekten bulunma hissini veren ve sosyalleşmeyi olumlu yönde etkileyen etkenlerden kabul edilmiştir (Dillenbourg ve diğerleri, 2002; Hu, Cai ve Wen, 2018; Minocha ve Hardy, 2016). Aynı zamanda tüm bu özellikler üç-boyutlu sanal dünyaların yüksek düzeyde etkileşim imkânı bulunan gerçekçi ortamlar olduğunun da bir göstergesidir (Rodriguez ve diğerleri, 2016).

Üç-boyutlu sanal ortamlarının tasarımsal etkileri üzerine yapılmış bir alanyazın incelemesinde ise 15 çalışma, pedagojik yaklaşım, öğrenci algıları ve karakteristik özellikler olmak üzere üç açıdan incelenmiştir. Elde edilen sonuçlara göre çalışmalarda yapılandırmacı ve yapısalcı yaklaşım anlayışının ele alındığı gözlemlenmiştir. Aynı zamanda katılımcıların teknolojiye karşı ön yargıları olmasına rağmen, iletişim ve işbirliğine dayalı araçlara karşı olumlu olarak yaklaşımları rapor edilmiştir. Ayrıca aynı araştırma üç-boyutlu sanal dünya sistemlerinin tasarlanması sürecinde öğrenme deneyimlerini destekleyebilmek için öğrenme hedeflerinin bulunması gerektiğini de belirtmiştir (Dass, Dabbagh ve Clark, 2011). Üç-boyutlu sanal dünyalarla ilgili olarak yapılan çalışmaları inceleyen bir araştırma, bu ortamların sağlık, endüstri, eğitim ve turizm gibi alanlarda sıklıkla kullanıldığını belirtmiştir. Aynı araştırmada teknoloji firmalarının son yıllarda yapmış oldukları yatırımların üç-boyutlu sanal dünya teknolojilerin eğitsel amaçlı kullanılmasında elde edilebilecek olan öğrenci kazanımlarını daha da arttıracağını ele almıştır (Martín-Gutiérrez, Mora, Añorbe-Díaz ve González-Marrero, 2017). Öğretmen adayları üzerinde uygulanan bir başka üç-boyutlu sanal dünya araştırmasında ise geliştirilen ortam geleneksel sınıf ortamına benzetilmiş ve öğretmen adaylarının rol oynama yöntemi ile mikro-öğretim uygulamaları yapması sağlanmıştır. Araştırma sonucu olarak teknolojiden kaynaklı olarak gelişen sınırlılıklar dışında olumlu geri bildirimler sağlanmıştır. Aynı araştırma öneri olarak üç-boyutlu sana dünyaların sağlık eğitimi vb. diğer eğitim alanlarında da kullanılabileceğini sunmuştur (Dalgarno, Gregory, Reiners ve Knox, 2016).

Öğrenmenin etkili ve verimli olarak yapılması için kullanılan işbirliğine dayalı öğrenme yönteminin teknoloji destekli olarak gerçekleştirildiği bir araştırmada ise bu öğrenme yönteminin sınırlılıklarından olan sosyal bulunuşluk algısını gidermek için etkili yöntemlerden biri olan üç-boyutlu sanal dünyaların kullanılabileceği önerisi sunulmuştur (Öztürk ve Deryakulu, 2011). Sosyal bulunuşluk açısından yapılan bir araştırmada ise üç-boyutlu sanal öğrenme ortamında, bireylerin sosyal bulunuşluk düzeyleri belirlenmiştir. Sonuç olarak üçboyutlu sanal ortamların kullanımının sosyal bulunuşluk düzeyini arttırdığı sonucu çıkmıştır (Küfrevioğlu, Topu, Çoban ve Göktaş, 2012). 
Üç-boyutlu sanal dünyalar kullanılarak yapılan başka bir araştırmada ise katılımcı öğrencilerin yaratıcılıklarını kullanarak amfibi araçlar tasarlamaları ve geliştirme sürecinde öğrenciler arasındaki iletişimin ve etkileşimin arttığına yönelik sonuçlar görülmüştür (Chen, 2017). Çin ve Amerika Birleşik Devletlerindeki katılımcılarla işbirliğine dayalı olarak gerçekleştirilmiş olan bir araştırmada ise çok-kullanıcılı sanal ortam olan Second Life kullanılarak İngilizcenin yabancı dil öğrenimi için kullanılması durumunda öğretmen adaylarının deneyimleri incelemiştir. Elde edilen sonuçlar katılımcıların bu sistemi heyecan verici olarak görmesi, yabancı dil öğretiminde tamamlayıcı bir rol oynadı̆̆ı ve imkânlarını arttırdığ1 yönündedir (Wang, Lefaiver, Wang ve Hunt, 2011). Benzer başka bir çalışmada ise yabancı dil eğitiminde Second Life uygulamasının kullanımının eğitimde özerkliği sağlayabilmek için ne gibi olanaklar sağladığını araştırmış ve sonuçlar üç-boyutlu sanal öğrenme ortamlarının eğitimde özerkliği desteklediği, işbirliğine dayalı öğrenme ve proje temelli öğrenme vb. birçok öğrenme modeline de platform olabileceği ve tüm bu sonuçlara ek olarak katılımcıların motivasyonunu da desteklediği yönünde çıkmıştır (Can, 2012).

2008 ve 2019 yılları arasında yayınlanan 13 deneysel araştırmanın bulgularına dayanarak yapılan bir meta-analiz çalışmasında elde veriler özellikle işbirliğine dayalı öğrenme koşullarında öğrencilerin tutumlarını ve öz yeterliliklerini geliştirdiği yönde çıkmıştır (Wang, Lan, Tseng, Lin ve Gupta, 2019). Üç-boyutlu sanal dünyaları öğretim stratejileri, yöntemleri ve tekniklerine göre inceleyen başka bir araştırmada ise deneysel öğrenmenin sanal dünya çalışmalarında en çok kullanılan stratejilerden olduğu sonucuna varılmıştır. Aynı zamanda bu araştırma kullanılan üç-boyutlu sanal dünyalarda anlatım ve göstermeye dayalı öğretme stratejilerinin sıklıkla kullanıldığından da bahsetmiştir (Koçak, Demirel, Yılmaz ve Göktaş, 2016). Bir diğer çalışmada ise üç-boyutlu sanal öğrenme ortamlarının potansiyellerinin öğrenmeye olan etkileri bağlamında inceleme gerçekleştirilmiş ve sanal öğrenme ortamlarının deneysel öğrenme için büyük firsat oluşturduğu, motivasyonu arttırdığı, zengin öğrenme içeriklerinin barındırılabildiği ve işbirliğine dayalı öğrenme ortamı olarak kullanıldığında daha etkili olduğu sonucu görülmüştür (Dalgarno ve Lee, 2010). Yapılan bir başka araştırmada ise üç-boyutlu sanal dünyaların öğrenme ortamlarının sağlamış olduğu imkânlardan faydalanarak geleneksel olarak adlandırılan yüz-yüze eğitimle birlikte kullanılması sağlanmıştır. Bu bağlamda yapılan araştırmada pedagojik, mantıksal ve teknik olarak inceleme yapılmış olup, yüz-yüze ve uzak erişimli kullanıcıları destekleyen ve kısıtlayan yönler ortaya çıkartılmıştır. Elde edilen sonuçlar, sanal öğrenme ortamlarını harmanlamış öğrenme ortamı olarak kullanmak isteyen eğitmenlere bir rehber olabilmesi niteliğinde çıkmıştır (Bower, Lee, ve Dalgarno, 2017).

Yapılan araştırmalar üç-boyutlu sanal dünyaların öğrenme ortamı olarak kullanılmasının etkili ve verimli sonuçlar yarattığını, işbirliğine dayalı öğretim ortamı olarak tasarlanması durumunda ise içerik açısından zengin sonuçlar verdiği, buna ek olarak etkileşim, iletişim ve motivasyonu olumlu yönde etkilediğini göstermiştir. Bu maddeler üç-boyutlu sanal dünyaların öğrenme ortamı olarak geliştirilmesi sürecinde kullanılan Salmon'un beş aşamalı modeli ile benzerlikler göstermektedir (Salmon, Nie ve Edirisingha, 2010). Bütün bu sonuçlar üç-boyutlu sanal dünyaların öğrenme ortamı olarak kullanılmasında bize sunduğu imkânlar olarak düşünülebilir fakat bu imkânların tüm üç-boyutlu sanal dünyalarda olacağı anlamına gelmez. Etkililik ve verimlilik kapsamında olumlu sonuçların elde edilmesi için üç-boyutlu sanal dünyaların tasarımlarında dikkat edilmesi gereken en önemli nokta, sanal ortamların geliştirilmesinde akademik dayanakların tasarım sürecinde kullanılması gerektiğidir (Barab ve 
diğerleri, 2004; Barab, Thomas, Dodge, Carteaux ve Tuzun, 2005). Yapılan araştırmalar üçboyutlu sanal dünyaların eğitim ortamı olarak kullanılmasında yaşanan problemlerin çoğunun teknik ve donanımsal olarak göstermektedir (Çoban ve Göktaş, 2013). Bu ortamların eğitimde kullanılması için geliştirilmesinde tüm kriterlerin bir bütün olarak ele alınıp sürecin işlemesi ve geliştirilen bu ortamların sık sık test edilerek geliştirilmesine devam edilmesi gerekmektedir (Tüzün, 2010).

$\mathrm{Bu}$ bağlamda üç-boyutlu sanal dünyaların eğitimde kullanılması durumunda etkili ve verimli sonuçlar elde edilebilmesi için bu sistemlerin tasarım sürecinde tüm kriterlerin doğru belirlenerek bir bütün olarak ele alınması gerekmektedir.

$\mathrm{Bu}$ araştırma üç-boyutlu sanal dünyaların işbirliğine dayalı öğretim ortamı olarak kullanılması amacıyla geliştirilmesi durumunda kullanıcı deneyimini etkileyen etkenlerin tespit edilmesi açısından bir rehber niteliğinde olacaktır.

$\mathrm{Bu}$ araştırmanın amacı işbirlikli öğrenmeyi destekleyen üç-boyutlu sanal dünyaların öğrenme ortamı olarak geliştirmek ve bu ortamların tasarlanması aşamasında kullanıcıların kullanımını kolaylaştıran ve kolay kullanımını engelleyen etkenlerin belirlenmesidir.

$\mathrm{Bu}$ amaç kapsamında işbirlikli öğrenmeyi destekleten üç-boyutlu sanal öğrenme ortamı geliştirilmiş ve bu ortam içerisinde katılımcılara verilen çeşitli etkinlikler ve görevler kapsamında aşağıdaki sorulara cevap aranmıştır:

1. İşbirlikli öğrenmeyi destekleyen üç-boyutlu sanal öğrenme ortamlarına karşı kullanıcıların;

a. Memnuniyet seviyesi nedir?

b. Memnuniyet durumlarına iliş̧kin görüşleri nelerdir?

2. İşbirlikli öğrenmeyi destekleyen üç-boyutlu sanal öğrenme ortamlarının geliştirilmesi için kullanımı kolaylaştıran etkenler nelerdir?

3. İşbirlikli öğrenmeyi destekleyen üç-boyutlu sanal öğrenme ortamlarının geliştirilmesi için kolay kullanımı engelleyen etkenler nelerdir?

\section{Yöntem}

$\mathrm{Bu}$ başlık altında araştırmanın modeli, çalışmada kullanılan sistemin geliştirme süreci, çalışma grubu, çalışmada kullanılan veri toplama araçları, veri toplama süreci ve analizin nasıl gerçekleştiğine değinilmiştir.

\section{Araştırma Modeli}

Araştırma modeli olarak nitel araştırma yöntemlerinden biri olan biçimlendirici araştırma (formative research) deseni kullanılmıştır. "Etkililik", "Verimlilik" ve "Çekicilik" gibi başlıklar üzerinde duran bu yöntem "Problem nedir?", "Mevcut durum nedir?", "Hangi stratejiler daha uygundur?", "Sistem nasıl geliştirilir?" ve "Geliştirmek için neler gereklidir?" vb. sorular üzerinde durmaktadır (Reigeluth ve Frick, 1999). Reigeluth ve Frick'e göre bu araştırma modeli, "Etkililik", "Verimlilik" ve "Çekicilik" açısından en üst düzeye ulaşabilmek için 
"Geliştirme" ve "Değerlendirme" basamaklarını içeren bir döngü içermektedir (Reigeluth ve Frick, 1999).

Temel amacı üç-boyutlu sanal dünyaların işbirlikli öğrenmeyi destekleyen eğitim ortamı olarak geliştirilmesi olan bu araştırmada alan yazın taramasının yapılmasının ardından, kağıt prototip ve eğitsel yapı oluşturulmuştur. Bu süreçte alan yazından elde edilen kriterler ile şekil 1 'de gösterilen işlevsiz üç-boyutlu model prototip bilgisayar programları yardımıyla çizilerek geliştirilmiştir. Oluşturulan bu prototipin bilgisayar çıktısı üzerinden sanal öğrenme ortamı olarak kullanabilmesi, işbirliğine dayalı sanal öğrenme ortamı olarak kullanılabilmesi, sistemin genel kullanılabilirliği vb. başlıklarda Bilgisayar ve Öğretim Teknolojileri Eğitimi bilim dalında görevli ve sanal dünyalar konusunda çalışan üç alan uzmanı öğretim üyesinden uzman görüşleri alınmıştır. Toplanan veriler sistemin geliştirilme sürecinin ilk aşaması olarak kabul edilen kriterleri oluşturmuştur.

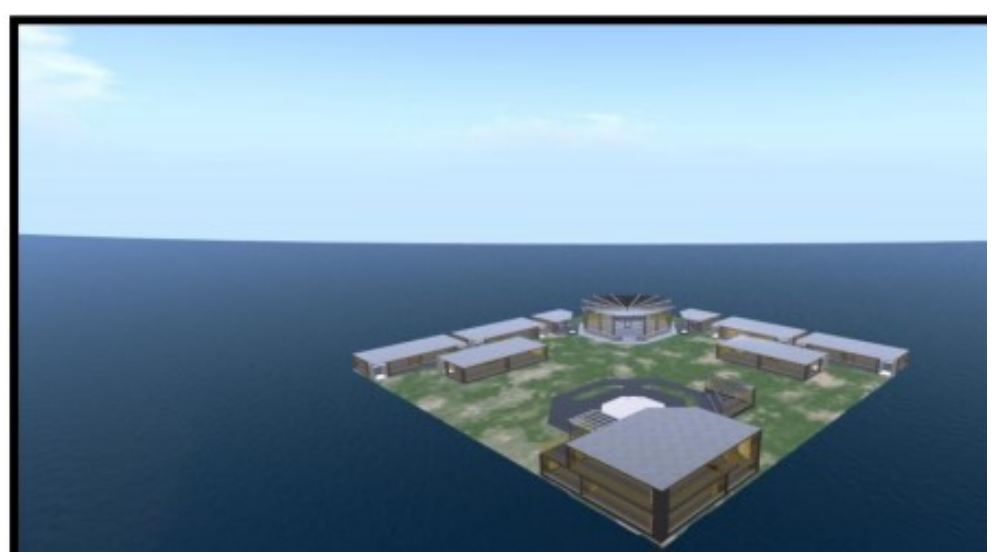

\section{Şekil1. Kağıt Prototip Kriterlerine Göre Oluşturulan İlk Üç-Boyutlu Model}

Kabul edilen kağıt prototip kriterlerine göre geliştirilen sanal öğrenme ortamı, bir kez daha uzman görüşüne sunulmuş ve elde edilen geri bildirimlere göre geliştirilen ortam düzenlenerek son aşamasına ulaşmıştır.

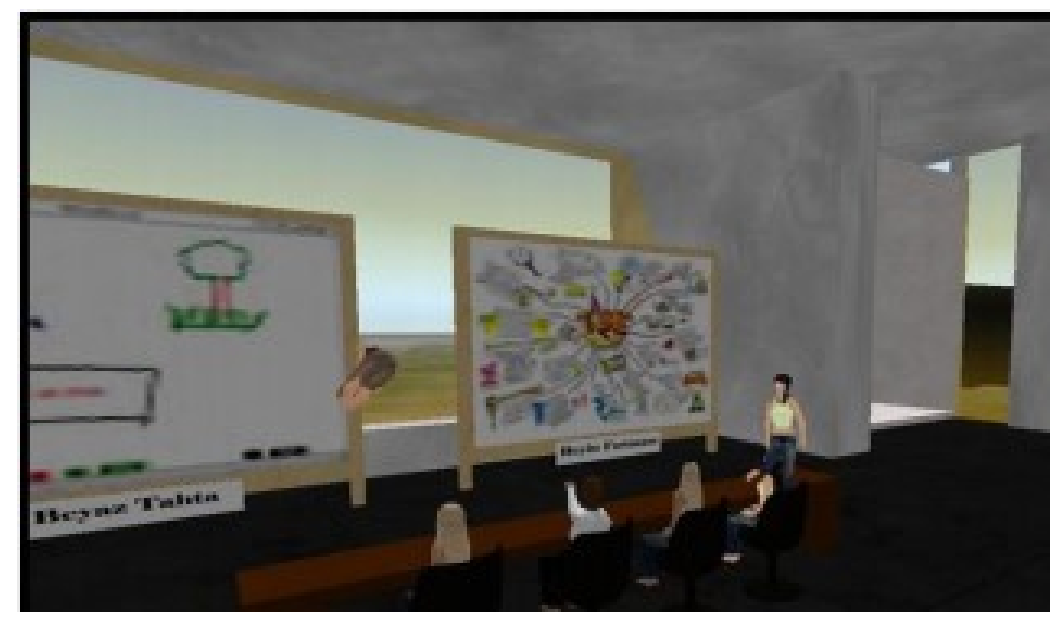

Şekil2. Pilot Uygulama Sürecinde Sistemi Kullanan Öğrenciler

Mevcut ortamın pilot uygulama sürecinde geliştirilen üç-boyutlu dünyanın uygulama sürecinde kullanılmış çalışma grubuna benzer özellikleri taşıyan başka bir grupla kısa süreli 
olarak kullanımı gerçekleştirilmiştir. Şekil 2'de gösterilen pilot uygulama sürecinin gerçekleşmesiyle birlikte katılımcılardan öğretim ortamı kullanım anketi ile geri bildirimler alınmış ve ortamın eksiklikleri olarak düşünülen kullanıcıların sistemi kolay kullanmasını engelleyen maddeler ortaya çıkartılmış ve düzenlemeler yapılmıştır. Bütün bu işlemlerin sonunda önceden belirlenen eğitsel amaç ve görevlerle geliştirilen sanal ortamın kullanıcılar üzerinde uygulaması gerçekleşmiş ve elde edilen sonuçlar araştırma sorularına göre geliştirme kriterlerini belirlemiştir.

Üç-boyutlu sanal dünyaların öğrenme ortamı olarak geliştirme sürecinde üç-boyutlu sanal ortamlardan biri olan "OpenSim" kullanılmıştır. "OpenSim" yazılımının tercih edilmesinin sebebi açık kaynak olmasının yanı sıra bir benzeri olan "Second Life" yazılımıyla karşılaştırıldığında daha ekonomik bir çözüm olmasıdır. Hem "Second Life" hem de "OpenSim" sistem içerisindeki kullanıcılarına koşma, yürüme vb. gerçek dünya işlemlerini gerçekleştirebildiği gibi uçma, 1şınlanma vb. işlemleri de gerçekleştirebilmesine olanak sağlamaktadır (Huvila, 2018; Wei, Huang, Wang, Zhang ve Wang, 2018).

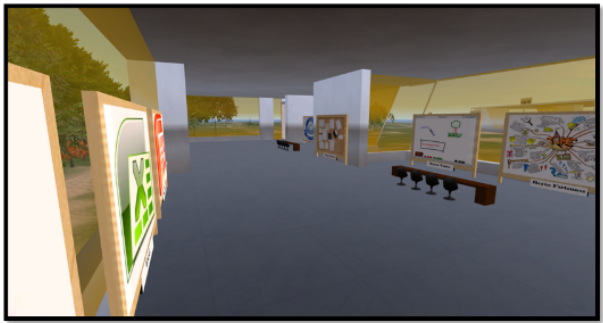

Şekil3. Grup Çalışma Odaları

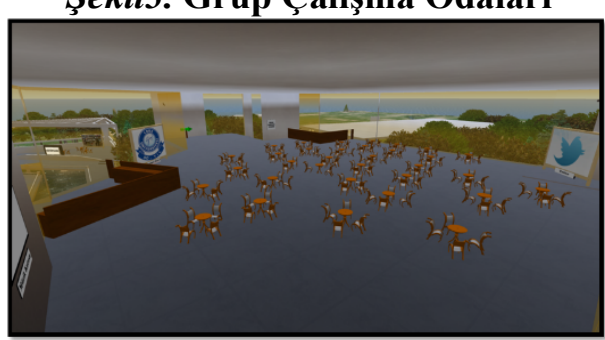

Şekil5. Sosyal Ortam - Kafeterya

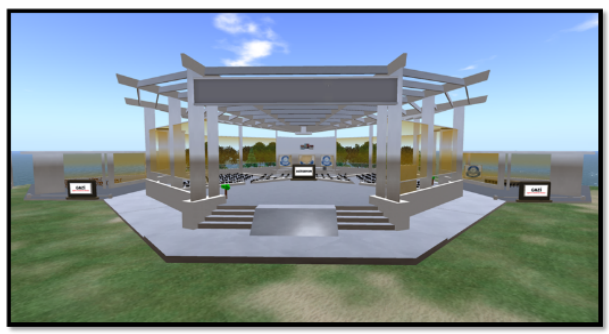

Şekil7. Oditoryum Alanı

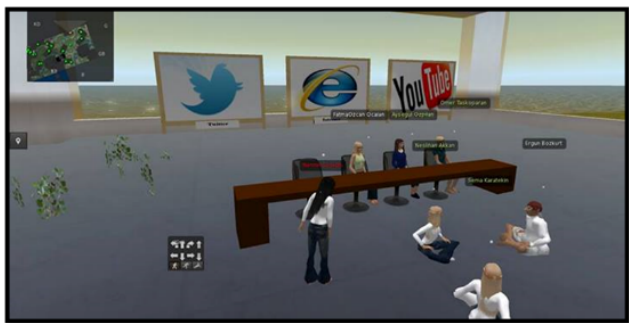

Şekil4. Grup Çalıșması Yapan Öğrenciler

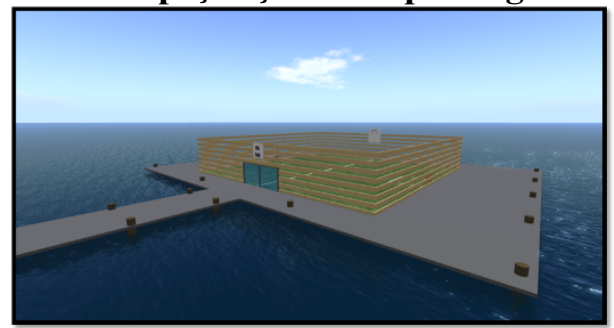

Şekil6. Spor Alanı - Futbol Sahası

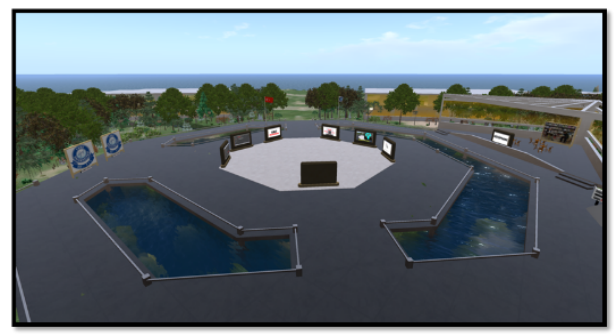

Şekil8. Oryantasyon Alanı

Geliştirilen ortam ile katılımcılar düzenlenen eğitim etkinliklerine katılmış ve uygulama sonunda ortamın kullanımıyla ilgili fikirlerini sunmuşlardır. Sanal Kampüs içerisinde; oryantasyon alanı, eğitim alanı ve eğlence alanı bulunmaktadır. Oryantasyon alanı, kullanıcıların ortama daha kolay adaptasyonunun sağlanması için çeşitli yönergelerin bulunduğu ortak alandır. Bu alan şekil 7 ve şekil 8'de gösterilmektedir. Eğlence alanı olarak tanımlanan alanlar ise, Sosyal Ortam ve Spor Alanı'dır. Bu ortamlarda ise kullanıcıların çeşitli eğlence 
içeren uygulamalara erişebilecekleri, avatarlarının görünümlerini değiştirebilecekleri ve sosyalleşebilecekleri öğeleri içermektedir. Şekil 5 ve şekil 6'da eğlence alanları gösterilmektedir. Eğitim alanı ise Grup Çalışma Odaları ve Oditoryum Alanından oluşmaktadır. $\mathrm{Bu}$ alanlar içerisin yer alan araçlar ise; beyin firtınası, sunu aracı, iletişim panosu, ofis araçları, beyaz tahta, vb. uygulamalardır. Eğitim ortamları ile ilgili görseller ise şekil 3 ve şekil 4'te gösterilmektedir.

\section{Çalışma Grubu}

Pilot ve uygulama süreçlerindeki katılımcılar Ankara ili içerisinde bulunan bir üniversitenin Bilgisayar ve Öğretim Teknolojisi Öğretmenliği bölümündeki 56 öğrencilerden oluşmaktadır Uygulama sürecinde yer alan 56 kişiden 22 tanesi erkek, 34 tanesi ise kız öğrencidir. Katılımcıların hepsi üç-boyutlu sanal öğrenme ortamlarını kullanabilecek bilgisayar okuryazarlık seviyesine sahiptir. Katılımcıların büyük çoğunluğu benzer üç-boyutlu sanal öğrenme ortamlarını daha önce hiç kullanmamış olmasına rağmen, bu ortamlar hakkında genel bir bilgiye sahiptir.

Araştırmanın sorumlusu tarafindan grup seçiminde özgürlük tanınan öğrenciler çalışma gruplarını 5'erli olarak kendileri oluşturmuşlardır. Öğrenci sayısından kaynaklı olarak tüm gruplar 5'er kişiden oluşurken gruplardan bir tanesi ise 6 kişiden oluşmuştur. Bu öğrenciler işbirlikli öğrenmeyi destekleyen üç-boyutlu sanal dünya içerisinde kendi grupları için özel olarak oluşturulan çalışma odalarında kendilerine verilen görevleri eğitim saatleri dışında grup olarak tamamlamışlardır. Bu görevler eğitmen tarafından ders saatleri içerisinde verilen görevleri kapsamaktadır. Araştırma içerisinde katılımcılara tanınan grup seçme özgürlüğün araştırmaya olan etkisi üzerine herhangi bir veri toplama işlemi yapılmadığından öğrencilerin özgür bir şekilde çalışma gruplarını oluşturmaları araştırmanın sınırlılığı olarak kabul edilmektedir.

\section{Çalışmada Kullanılan Ölçme Araçları}

Veri toplama araçlarının geliştirilme aşamasında alan yazın çalışması gerçekleştirilmiş ve gerekli maddeler bu çalışmalardan referans alınarak veri toplama araçlarının son halini almasına katkı sağlamıştır. Veri toplama araçlarında yer alan bu maddeler üç-boyutlu sanal dünyaların eğitim amacıyla kullanılmasını sağlayan bileşenlerden oluşmaktadır. Oluşturulan araçlar dil ve alan uzmanları ile araştırmaya uygunluğu test edilmiş ve uzmanlardan gelen geri bildirimlere göre düzenlemeleri yapılmıştır. Bu araçlar "Görüşme Formu” ve "Öğretim Ortamı Kullanım Anketi" olmak üzere genel olarak iki kategoriden oluşmaktadır. "Öğretim Ortamı Kullanım Anketi" kendi içerisinde "Pilot" ve "Uygulama" olmak üzere ikiye ayrılırken "Görüşme Formu" ise sadece "Uygulama" sürecinde kullanılmıştır.

Geliştirilen veri toplama araçları genel olarak "erişim", "iletişim”, "eğitim”, "sanal dünya", "kullanım", "işbirlikli eğitim" ve "sosyal ortam" bileşenlerini içermektedir. Araştırmaya katılan kullanıcılara bu bileşenleri kontrol edebilecekleri görevler verilmiş ve bu görevler kapsamında ölçme araçlarıyla deneyimleri hakkında bilgi alınmıştır. Örnek vermek gerekirse; "Sanal dünya içerisinde arkadaşlarınızla sesli ve yazılı olarak iletişim kurunuz." olarak verilen bir görev için kullanım anketinde yer alan görevle ilgili olarak "Sanal kampüs içerisinde sınıf arkadaşlarım ile iletişim kurabildim.", "Sanal kampüs içerisinde grup arkadaşlarım ile iletişim kurabildim" vb. maddeleri bireysel olarak puanlaması istenmiştir. Buna 
ek olarak kullanıcı ile yapılan görüşmelerde ise bu görevle ilgili "iletişim", "sanal dünya", "kullanım", "sosyal ortam" gibi bileşenler üzerinde kullanımını kolaylaştıran, zorlaştıran ve memnuniyetiyle ilgili konularda görüşleri alınmıştır.

\section{Öğretim Ortamı Kullanım Anketi - Pilot}

Sanal Kampüs Pilot süreç içerisinde sistem kullanımını kolaylaştıran ve kolay kullanımını engelleyen etkenleri bulmak için hazırlanmış bir veri toplama aracıdır. Bu anket "Erişim", "Kullanım”, "Öğretim Araçları", "Ortam Araçları" ve "Eğitim” başlıkları altında 15 adet açık uçlu sorudan oluşmaktadır. Yapılan kullanım anketi katılımcılardan gelen geri bildirimler, uzman görüşleri ve araştırmacının gözlemlerine göre değişikliklere uğramıştır. Bu değişiklikler kullanılan teknoloji ile toplanan kayitların katılımcilara sorulması yerine mevcut sistemin alt yapısı kullanılarak toplanması vb. gibidir.

\section{Öğretim Ortamı Kullanım Anketi - Uygulama}

Sanal Kampüs ortamının uygulama süreci içerisinde kullanıcının memnuniyet seviyesini, sistem kullanımını kolaylaştıran ve kolay kullanımını engelleyen etkenleri bulmak için hazırlanmış bir veri toplama aracıdır. Bu anket 5'li likert tipi Sanal Kampüs kullanımını ölçen 31 maddeden ve 14 adet açık uçlu sorudan oluşmaktadır. Likert tipi anket soruları "Erişim", "İletişim", "Eğitim", "Öğretim Araçları" ve "Sanal Dünya" başlıkları altındayken, açık uçlu sorular ise "Erişim", "Kullanım”, “Öğretim Araçları", "Ortam Araçları" ve " Diğer” başlıkları altında toplanmıştır.

\section{Görüşme Formu - Uygulama}

Sanal Kampüs ortamın kullanımını kolaylaştıran ve kolay kullanımını engelleyen etkenlerinin yanında katılımcılar açısından memnuniyet ile ilgili görüşlerinin tespit edilebilmesi için hazırlanmış yarı-yapılandırılmış bir veri toplama aracıdır. Görüşme formu "Erişim", "İletişim", "Eğitim", "Sanal Dünya", "Kullanım", "İşbirliğine Dayalı Eğitim” ve "Sosyal Ortam" başlıklarından oluşmaktadır.

\section{İşlem}

Geliştirilen üç-boyutlu sanal dünyaların öğretim ortamı olarak kullanılması sürecinde çalışmanın amacına hizmet eden bir "Görev Listesi" ile pilot gruba uygulanmıştır. "Görev Listesi” olarak adlandırılan listede yer alan bazı maddeler şu şekildedir:

- Çalışacağınız konuya grubunuz için özel olarak ayrılan alanda gerekli araçları kullanarak karar veriniz.

- Grubunuz için özel olarak ayrilan alanda Word, Excel ve PowerPoint kullanarak belirlediğiniz konuyla ilgili olarak çalışınız.

- Kütüphaneden konunuzla ilgili çalışmaları inceleyiniz.

$\mathrm{Bu}$ vb. görevlerin kullanıcılar tarafından geliştirilen ortamlarda tamamlanması beklenmiştir. Kullanıcıların görevleri tamamlama süreçlerinde araştırmacılar danışman olarak bulunmuşlarıdır. $\mathrm{Bu}$ uygulama sonunda katılımcıların sistem hakkındaki deneyimlerine dayanarak "Öğretim Ortamı Kullanım Anketi” ile veri toplama işlemi yapılmıştır. 


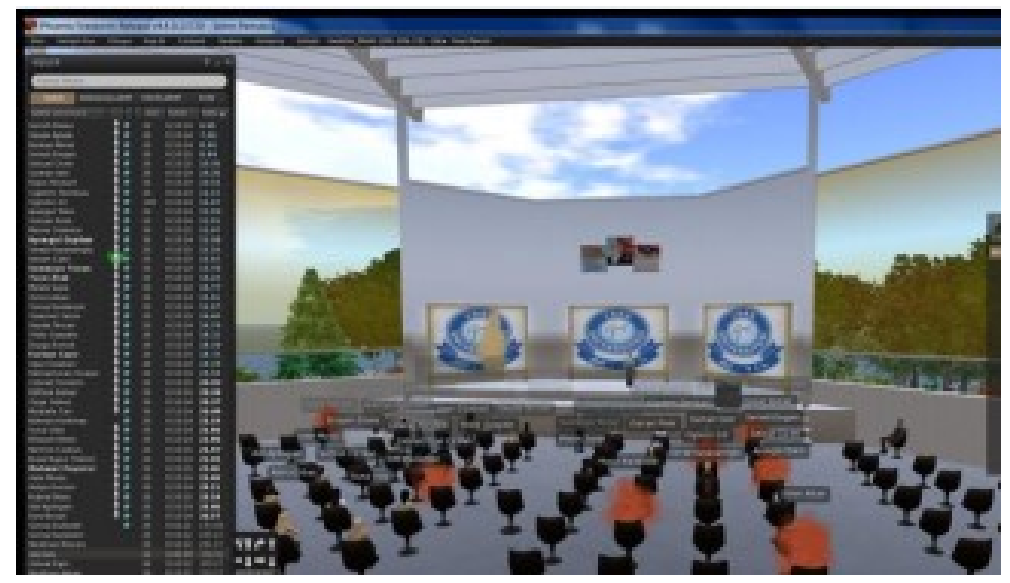

Şekil9. Oditoryumda Eğitmen Ders Anlatırken

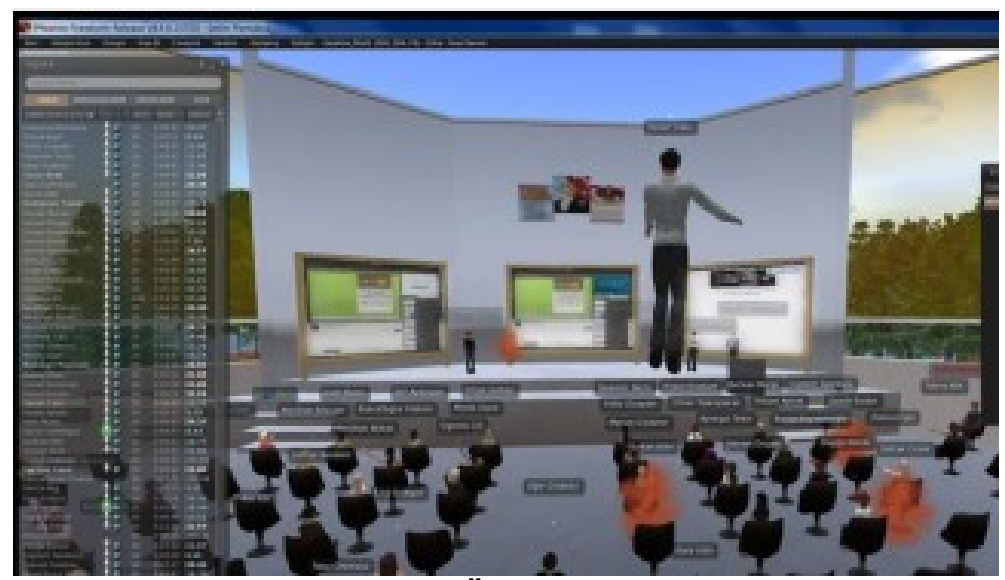

Şekil10. Oditoryumda Öğrenciler Sunum Yaparken

Pilot uygulama sonrasında gerçekleştirilen uygulama sürecinden bazı ekran görüntüleri şekil 4, şekil 9 ve şekil 10'da gösterilmektedir. Uygulama sürecinin ilk haftasında kullanıcılara "Görev Listesi" verilerek bazı görevleri yapmaları ve aynı zamanda katılımcıların görevlerle veya sistemle ilgili sorunlarını da "Kampüs Defteri" isimli araca yazmaları istenmiştir. 6 hafta boyunca devam eden bu süreç katılımcıların araştırmacılar tarafından daha önceden belirlenen saatlerde senkron olarak eğitimlere katılması ve eğitim saatleri dışında ise asenkron olarak görevlerini tamamlamaları üzerine inşa edilmiştir. Senkron olarak devam eden eğitimlerde katılımcıların yaşadıkları problemler araştırmacılar tarafından anında çözülmeye çalışılırken, asenkron olarak kullanılan süreçlerde ise "Kampüs Defteri" olarak adlandırılan araç ile veriler toplanmıştır. Toplanan bu maddeler değerlendirilerek veri toplama işlemine de katkıda bulunmuştur.

Uygulama sürecinin başlangıç haftasında oryantasyon ortamlarında bulunan kullanıcılar sistemin kullanımını öğrenmiş, senkron eğitim süreçlerinde oditoryum alanında eğitimlere katılmışlardır. Bunun dışında olan bulunan zamanlarda ise eğlence alanlarında sosyalleşme ve eğlence faktörü bulunan araçları kullanabildikleri gibi kendi çalışma gruplarıyla yürüttükleri çalışmalarına da eğitim ortamlarında devam etmişlerdir.

Uygulama sürecinin sona ermesi ile katılımcılara "Öğretim Ortamı Kullanım Anketi" verilerek doldurmaları istenmiş ve bu ankete 56 öğrenci dönüş yapmıştır. Anket doldurma 
işlemlerinin ardından gruplar ile özel olarak yarı-yapılandırılmış görüşmeler yapılmıştır ve bu görüşmeler sırasında çeşitli notlar "Görüşme Formu" ile araştırmacı tarafından not edilmiştir. Yapılan görüşmeler geliştirilen üç-boyutlu sanal öğrenme ortamı üzerinden her bir grup için yaklaşık 2.5 saat olmak üzere toplam 49 öğrencinin katılımı ile gerçekleşmiştir. Genel olarak görüşmeler için geliştirilen üç-boyutlu öğretim ortamı kullanılmasına rağmen bazı teknik problemler yaşandığı zamanlarda sürecin ilerlemesinde herhangi bir aksaklık olmaması için "Google Hangouts" veya "Adobe Connect" ile görüşmelere devam edilmiştir. Veri toplama sürecinin aksamaması için kullanılan diğer ortamlar sadece görüşme süreçlerinde kullanılmış ve yapılan araştırmalarda kullanılan veri toplama yöntem farklılığının sonuçlara etki etmemesinden kaynaklı olarak alternatif olarak değerlendirilmiştir (Schillewaert ve Meulemeester, 2005).

Öğretim ortamının pilot çalışmasının tamamlanmasının ardından gerçekleştirilen veri toplama süreci ile araştırmacılar tarafından betimsel analizler yapılmış ve elde edilen veriler "olumlu" ve "olumsuz" olmak üzere kodlanmıştır. Bu kodlamaya sistem içerisinde kullanılan kayıt defterleri de katkı sağlamıştır. "Olumlu" ve "Olumsuz" olmak üzere toplanan verilere göre "Sanal Kampüs” üzerinde değişiklikler gerçekleştirilmiş ve ortamın eksiklikleri giderilerek geliştirilmeye çalışılmıştır.

Uygulamanın sonuçlanması ile kullanım anketi içerisindeki açık uçlu soruların kodlanması içerik analizi ile "erişim ve iletişim", "kullanılabilirlik", "eğitim ortamı" ve "sosyal ortam" başlıkları altında yapılmıştır. Aynı anket içerisindeki nicel veriler frekans değerlerine göre ortalama ve standart sapma olmak üzere betimlenmesi yapılmış ve elde edilen bu sayısal veriler memnuniyet seviyesi ile ilgili araştırma sorusuna cevap olarak düşünülmüştür. İçerik analizi sonucunda memnuniyet ile ilgili görüşler yine aynı soruda cevaplanmıştır. Son olarak uygulama grubuyla yapılan görüşmelerden toplanan veriler de anket verileri gibi içerik analizi yapılarak aynı başlıklar altında kodlaması tamamlanmış ve sınıflandırılmıştır.

İçerik analizinde oluşturulan maddeler aralarındaki ilişkilere göre kod ve temalara dönüştürülmüş̧tür. Bu kodlar alan uzmanı olan bir kişi tarafından incelenmiş ve uygunluğu onaylanmıştır. Bu süreç içerisinde kodlamalar araştırmanın sorularını cevaplayacak formatta 45 maddeye dönüştürülmüştür. İçerik analizi aşamasında güvenirliğin sağlanması açısından kodlama işlemi araştırmacıların dışında başka bir uzman kişi tarafından daha yapılmış ve iki kodlama arasında 39 madde birbiriyle eşleşmiştir. 6 madde ise araştırmacılar ve uzman tarafından farklı temalar altında kodlanmıştır. İki araştırmacının analizlerinin eşleşme oranı \%86,66'dir. Araştırmacılar ve uzman kişi tarafından aynı başlık altında eşleşmeyen 6 madde üzerinde görüşme yapılarak ortak bir fikre varılmış ve kodlama işlemi tamamlamıştır. Bu rakamlar araştırmacılar arası tutarlılığı ve ortaya konulan kod şemasının geçerliliğini ve güvenirliğini sağlamıştır.

\section{Bulgular}

Yapılan analizler sonucunda elde edilen bulgular araştırma sorularının başlıkları altında incelenmiştir.

\section{İşbirlikli öğrenmeyi destekleyen üç-boyutlu sanal öğrenme ortamlarına karşı kullanıcıların memnuniyet seviyesi nedir?}


Öğretim ortamı kullanım anketi ile elde edilen sayısal veriler; "Erişim”, "İletişim”, "Eğitim”, "Öğretim Araçları" ve "Sanal Dünya" başlıkları altında kullanıcıların işbirlikli öğrenmeyi destekleyen üç-boyutlu sanal öğrenme ortamına karşı memnuniyet seviyeleri analiz edilmiştir.

Tablo 1. Erişimle İlgili Kullanıcı Memnuniyet Puanları

\begin{tabular}{lccccc}
\hline ERIşìiM & N & Min & Max & X & SD \\
\hline $\begin{array}{l}\text { Sanal kampüs içerisinde bulunan bütün ortamlara } \\
\text { erişebildim. }\end{array}$ & 56 & 1 & 5 & 3,89 & 0,504 \\
$\begin{array}{l}\text { Sanal kampüs içerisinde istediğim yere 1şınlanabildim. } \\
\begin{array}{l}\text { Sanal kampüs için hazırlanan erişim yönergeleri } \\
\text { yeterliydi. }\end{array}\end{array} \quad 56$ & 1 & 5 & 3,68 & 0,473 \\
\begin{tabular}{l} 
Sanal kampüse problemsiz giriş yapabildim. \\
\hline
\end{tabular} & 56 & 1 & 5 & 3,23 & 0,432 \\
\hline
\end{tabular}

İşbirlikli öğrenmeyi destekleyen üç-boyutlu sanal öğrenme ortamına erişimle ilgili kullanıcı memnuniyet puanlanı tablo 1'de ortalaması en yüksek olandan en düşük olana doğru sıralanarak sunulmuştur. Buna göre; "Sanal kampüs içerisinde bulunan bütün ortamlara erişebildim" ortalaması $\mathrm{X}=3,89$, standart sapması $\mathrm{SD}=0,504$ olarak, "Sanal kampüs içerisinde istediğim yere ışınlanabildim" ortalaması $\mathrm{X}=3,68$, standart sapması $\mathrm{SD}=0,473$ olarak, "Sanal kampüs için hazırlanan erişim yönergeleri yeterliydi" ortalaması $X=3,68$, standart sapması $\mathrm{SD}=0,473$ olarak ve "Sanal kampüse problemsiz giriş yapabildim" ortalaması $\mathrm{X}=3,23$, standart sapması $\mathrm{SD}=0,432$ olarak hesaplanmıştır.

Tablo 2. İletişimle İlgili Kullanıcı Memnuniyet Puanları

\begin{tabular}{lccccc}
\hline ILETIŞ̧іM & N & Min & Max & X & SD \\
\hline $\begin{array}{l}\text { Sanal kampüs içerisinde eğitmenler ile iletişim } \\
\text { kurabildim. }\end{array}$ & 56 & 1 & 5 & 4,55 & 0,633 \\
$\begin{array}{l}\text { Sanal kampüs içerisinde grup arkadaşlarım ile iletişim } \\
\text { kurabildim. }\end{array}$ & 56 & 2 & 5 & 4,55 & 0,633 \\
$\begin{array}{l}\text { Sanal kampüs içerisinde sınıf arkadaşlarım ile iletişim } \\
\text { kurabildim. }\end{array}$ & 56 & 2 & 5 & 4,48 & 0,618 \\
$\begin{array}{l}\text { Sanal kampüs içerisinde diğer avatarlar ile sesli ve } \\
\text { yazılı olarak yeterince iletişim kurabildim. }\end{array}$ & 56 & 2 & 5 & 4,16 & 0,552 \\
$\begin{array}{l}\text { Sanal kampüs içerisinde yaşadığım problemler için } \\
\text { aldığım çözüm önerileri yeterliydi. }\end{array}$ & 56 & 1 & 5 & 3,95 & 0,513 \\
$\begin{array}{l}\text { Sanal kampüs içerisinde diğer avatarlar ile iletişim } \\
\text { tahtaları aracılığıyla yeterince iletişim kurabildim. }\end{array}$ & 56 & 1 & 5 & 3,34 & 0,439 \\
\hline
\end{tabular}

İşbirlikli öğrenmeyi destekleyen üç-boyutlu sanal öğrenme ortamına iletişimle ilgili kullanıcı memnuniyet puanları tablo 2'de ortalaması en yüksek olandan en düşük olana doğru sıralanarak sunulmuştur. Buna göre; "Sanal kampüs içerisinde eğitmenler ile iletişim 
kurabildim" ortalaması $\mathrm{X}=4,55$, standart sapması $\mathrm{SD}=0,633$ olarak, "Sanal kampüs içerisinde grup arkadaşlarım ile iletişim kurabildim" ortalaması $X=4,55$, standart sapması $\mathrm{SD}=0,633$ olarak, "Sanal kampüs içerisinde sınıf arkadaşlarım ile iletişim kurabildim" ortalaması $X=4,48$, standart sapması $\mathrm{SD}=0,618$ olarak, "Sanal kampüs içerisinde diğer avatarlar ile sesli ve yazılı olarak yeterince iletişim kurabildim" ortalamas $\mathrm{X}=4,16$, standart sapması $\mathrm{SD}=0,522$ olarak, "Sanal kampüs içerisinde yaşadığım problemler için aldığım çözüm önerileri yeterliydi” ortalaması $\mathrm{X}=3,95$, standart sapması $\mathrm{SD}=0,513$ olarak, "Sanal kampüs içerisinde diğer avatarlar ile iletişim tahtaları aracılığıyla yeterince iletişim kurabildim" ortalaması $\mathrm{X}=3,34$, standart sapması $\mathrm{SD}=0,439$ olarak hesaplanmıştır.

Tablo 3. Eğitimle İlgili Kullanıcı Memnuniyet Puanları

\begin{tabular}{lccccc}
\hline EĞíTiM & N & Min & Max & X & SD \\
\hline $\begin{array}{l}\text { Sanal kampüs ortamı diğer uzaktan eğitim ortamlarına } \\
\text { göre daha uygundu. }\end{array}$ & 56 & 1 & 5 & 4,13 & 0,545 \\
$\begin{array}{l}\text { Sanal kampüsü bir eğitim ortamı olarak kullanılması } \\
\text { için tavsiye ederim. }\end{array}$ & 56 & 1 & 5 & 3,73 & 0,480 \\
$\begin{array}{l}\text { Sanal kampüs eğitim ortamı olabilmesi açısından } \\
\text { yeterliydi. }\end{array}$ & 56 & 1 & 5 & 3,63 & 0,466 \\
$\begin{array}{l}\text { Sanal kampüs içerisinde gerçekleştirilecek diğer } \\
\text { eğitimlere katılırım. }\end{array}$ & 56 & 1 & 5 & 3,63 & 0,466 \\
$\begin{array}{l}\text { Sanal kampüs ortaminnda gerçekleştirilen eğitimin } \\
\text { verimli olduğunu düşünüyorum. }\end{array}$ & 56 & 1 & 5 & 3,50 & 0,452 \\
$\begin{array}{l}\text { Sanal kampüs ortamı yüz yüze eğitim ortamlarına göre } \\
\text { daha uygundu. }\end{array}$ & 56 & 1 & 5 & 2,88 & 0,428 \\
\hline
\end{tabular}

İşbirlikli öğrenmeyi destekleyen üç-boyutlu sanal öğrenme ortamında eğitimle ilgili kullanıcı memnuniyet puanları tablo 3'de ortalaması en yüksek olandan en düşük olana doğru sıralanarak sunulmuştur. Buna göre; "Sanal kampüs ortamı diğer uzaktan eğitim ortamlarına göre daha uygundu" ortalaması $\mathrm{X}=4,48$, standart sapması $\mathrm{SD}=0,618$ olarak, "Sanal kampüsü bir eğitim ortamı olarak kullanılması için tavsiye ederim" ortalaması $\mathrm{X}=3,73$, standart sapması $\mathrm{SD}=0,480$ olarak, "Sanal kampüs eğitim ortamı olabilmesi açısından yeterliydi" ortalaması $\mathrm{X}=3,63$, standart sapması $\mathrm{SD}=0,466$ olarak, "Sanal kampüs içerisinde gerçekleştirilecek diğer eğitimlere katılırım" ortalaması $\mathrm{X}=3,63$, standart sapması $\mathrm{SD}=0,466$ olarak, "Sanal kampüs ortamında gerçekleştirilen eğitimin verimli olduğunu düşünüyorum" ortalaması $X=3,50$, standart sapmas1 $\mathrm{SD}=0,452$ olarak, "Sanal kampüs ortamı yüz yüze eğitim ortamlarına göre daha uygundu" ortalaması $\mathrm{X}=2,88$, standart sapması $\mathrm{SD}=0,428$ olarak hesaplanmıştır.

Tablo 4. Öğretim Araçlarıyla İlgili Kullanıcı Memnuniyet Puanları

\begin{tabular}{lccccc}
\hline ÖĞRETIM ARAÇLARI & N & Min & Max & X & SD \\
\hline $\begin{array}{l}\text { Grup odaları içerisindeki öğretim araçları eğitimsel } \\
\text { açıdan uygundu. }\end{array}$ & 56 & 1 & 5 & 3,95 & 0,513
\end{tabular}


Oditoryum içerisindeki öğretim araçları eğitimsel açıdan uygundu.

$\begin{array}{lllll}56 & 1 & 5 & 3,88 & 0,501 \\ 56 & 1 & 5 & 3,84 & 0,496 \\ 56 & 1 & 5 & 3,79 & 0,488 \\ 56 & 1 & 5 & 3,66 & 0,471\end{array}$

Grup odaları içerisindeki öğretim araçları sayısal olarak yeterliydi.

Oditoryum içerisindeki öğretim araçları sayısal olarak yeterliydi.

Sanal kampüs içerisindeki öğretim araçlarını kullanabildim.

İşbirlikli öğrenmeyi destekleyen üç-boyutlu sanal öğrenme ortamındaki öğretim araçlarıyla ilgili kullanıcı memnuniyet puanları tablo 4'de ortalaması en yüksek olandan en düşük olana doğru sıralanarak sunulmuştur. Buna göre; "Grup odaları içerisindeki öğretim araçları eğitimsel açıdan uygundu" ortalaması $\mathrm{X}=3,95$, standart sapması $\mathrm{SD}=0,513$ olarak, "Oditoryum içerisindeki öğretim araçları eğitimsel açıdan uygundu" ortalaması $X=3,88$, standart sapması $\mathrm{SD}=0,501$ olarak, "Grup odaları içerisindeki öğretim araçları sayısal olarak yeterliydi" ortalaması $\mathrm{X}=3,84$, standart sapması $\mathrm{SD}=0,496$ olarak, "Oditoryum içerisindeki öğretim araçları sayısal olarak yeterliydi” ortalaması $\mathrm{X}=3,79$, standart sapması $\mathrm{SD}=0,488$ olarak, "Sanal kampüs içerisindeki öğretim araçlarını kullanabildim" ortalaması $X=3,66$, standart sapması $\mathrm{SD}=0,471$ olarak hesaplanmıştır.

Tablo 5. Sanal Dünyalarla İlgili Kullanıcı Memnuniyet Puanları

\begin{tabular}{|c|c|c|c|c|c|}
\hline SANAL DÜNYA & $\mathbf{N}$ & Min & Max & $\mathbf{X}$ & SD \\
\hline $\begin{array}{l}\text { Sanal dünya içerisinde uçma etkinliği } \\
\text { gerçekleştirebildim. }\end{array}$ & 56 & 2 & 5 & 4,59 & 0,641 \\
\hline Sanal dünya tasarımsal açıdan yeterince uygundu. & 56 & 1 & 5 & 3,91 & 0,507 \\
\hline $\begin{array}{l}\text { Sanal dünya içerisindeki sosyal ortamlar sayısal olarak } \\
\text { yeterliydi. }\end{array}$ & 56 & 1 & 5 & 3,91 & 0,507 \\
\hline Sanal dünyaların kullanılması için tavsiye ederim. & 56 & 1 & 5 & 3,71 & 0,478 \\
\hline Sanal dünya içerisindeki navigasyon yeterliydi. & 56 & 1 & 5 & 3,64 & 0,468 \\
\hline Sanal dünya gerçeklik hissi yarattı. & 56 & 1 & 5 & 3,48 & 0,451 \\
\hline Sanal dünyaları kullanmaya devam edeceğim. & 56 & 1 & 5 & 3,46 & 0,449 \\
\hline Avatarım için sunulan görünüm seçenekleri yeterliydi. & 56 & 1 & 5 & 3,18 & 0,430 \\
\hline $\begin{array}{l}\text { Sanal dünya içerisine istediğim nesneleri tasarım } \\
\text { araçları ile inşa edebildim. }\end{array}$ & 56 & 1 & 5 & 3,14 & 0,429 \\
\hline $\begin{array}{l}\text { Sanal dünya içerisinde oluşturduğum karakter beni } \\
\text { yansitıyordu. }\end{array}$ & 56 & 1 & 5 & 2,95 & 0,427 \\
\hline
\end{tabular}


İşbirlikli öğrenmeyi destekleyen üç-boyutlu sanal öğrenme ortamıyla ilgili genel kullanıcı memnuniyet puanları tablo 5'de ortalaması en yüksek olandan en düşük olana doğru sıralanarak sunulmuştur. Buna göre; "Sanal dünya içerisinde uçma etkinliği gerçekleştirebildim" ortalaması $\mathrm{X}=4,59$, standart sapmas $1 \mathrm{SD}=0,641$ olarak, "Sanal dünya tasarımsal açıdan yeterince uygundu" ortalaması $\mathrm{X}=3,91$, standart sapması $\mathrm{SD}=0,507$ olarak, "Sanal dünya içerisindeki sosyal ortamlar sayısal olarak yeterliydi" ortalaması $\mathrm{X}=3,91$, standart sapmas1 $\mathrm{SD}=0,507$ olarak, "Sanal dünyaların kullanılması için tavsiye ederim" ortalaması $X=3,71$, standart sapmas $\mathrm{SD}=0,478$ olarak, "Sanal dünya içerisindeki navigasyon yeterliydi" ortalaması $\mathrm{X}=3,64$, standart sapması $\mathrm{SD}=0,468$ olarak, "Sanal dünya gerçeklik hissi yarattı" ortalaması $\mathrm{X}=3,48$, standart sapması $\mathrm{SD}=0,451$ olarak, "Sanal dünyaları kullanmaya devam edeceğim" ortalamas $\mathrm{X}=3,46$, standart sapması $\mathrm{SD}=0,449$ olarak, "Avatarım için sunulan görünüm seçenekleri yeterliydi" ortalaması $\mathrm{X}=3,18$, standart sapması $\mathrm{SD}=0,430$ olarak, "Sanal dünya içerisine istediğim nesneleri tasarım araçları ile inşa edebildim" ortalaması $X=3,14$, standart sapması $S D=0,429$ olarak, "Sanal dünya içerisinde oluşturduğum karakter beni yansittyordu" ortalaması $X=2,95$, standart sapması $\mathrm{SD}=0,427$ olarak hesaplanmıştır.

Öğretim ortamı kullanım anketinden elde edilen verilere göre genel memnuniyet ortalaması 3,75 olarak hesaplanmıştır. Elde edilen sonuçlara göre sayısal veriler genel olarak yorumlandığında kullanıcılardan bazılarının sistemin kullanımında bir takım problemler yaşadığı görülmektedir fakat buna rağmen elde edilen sonuçların ölçek ortalamasının üzerinde olduğu da görülmüştür. Bu da geliştirilen sanal öğrenme ortamının memnuniyet seviyesinin kullanıcılar açısından düşük olmadığı şeklinde yorumlanabilir.

\section{İşbirlikli öğrenmeyi destekleyen üç-boyutlu sanal öğrenme ortamlarına karşı kullanıcıların memnuniyet durumlarına ilişsin görüşleri nedir?}

Kullanıcılardan alınan diğer verilerin analizleri sonucunda da kullanıcının olumlu ve olumsuz yönde memnuniyet durumlarına ilişkin görüşlerini ifade eden bileşenler tespit edilmiştir. Tablo 6'da kullanıcı memnuniyet durumlarına ilişkin görüşleri kod ve tema tablosu gösterilmektedir.

Tablo 6. Kullanıcı Memnuniyet Durumlarına İlişsin Görüşleri Kod ve Tema Tablosu

\begin{tabular}{|c|c|}
\hline TEMA & KOD \\
\hline $\begin{array}{l}\text { Memnuniyet Durumlarına İlişkin Olumlu } \\
\text { Görüşleri }\end{array}$ & $\begin{array}{ll}\text { - } & \text { İletişim araçları açısından zengin olması } \\
\text { - } & \text { Teknik destek alabilmek için danışmanın } \\
\text { olması } \\
\text { - } & \text { Katılımcıların eğitim araçlarından anında } \\
\text { - } & \text { Reribildirim alabilmesi } \\
\text { - } & \text { sağlana davranmasılarına olanak } \\
\text { - } & \text { Uygulama sonrası sistemi kullanma } \\
\text { - } & \text { Asteği } \\
\text { Avatarların istenildiği gibi } \\
\text { düzenlenebildiği }\end{array}$ \\
\hline Memnuniyet Durumlarına İlişkin Olumsuz & - $\quad$ Spor ve sosyal etkinliklerin az olması \\
\hline
\end{tabular}


- Avatarların insani özelliklerinin bulunmamas1

Memnuniyetin olumlu yönde bulunduğu bulgular aşağıdaki kodlarla gösterilmektedir:

- İletişim araçları açısından zengin olması: Katılımcılar bu sistemi uygulama dışında iletişim amacıyla da kullanmışlardır. Katılımcılardan biri "Sanal kampüs sinavlara arkadaşlarımızla çalışmamıza imkân sağlamıştır." diye bir yorum yapmıştır.

- Teknik destek alabilmek için danışmanın olması: Süreç boyunca katılımcıların yaşadıkları teknik problemler araştırmacılar tarafından çözülmeye çalışılmıştır. Sistemde teknik destek alabilecekleri birinin bulunmasını memnun edici olarak belirtilirken, bazı katılımcıların araştırmacıyı veya eğitmeni her problemlerinde rahatsız etmemek için "Slkça sorulan sorular tablosu yapılmalıydı" diye belirttikleri raporlanmıştır.

- Katılımcıların eğitim araçlarından anında geri bildirim alabilmesi: Konu anlatımının ve proje sunumlarının yapıldığı oditoryum alanı içerisinde katılımcılar eğitmene soru sorabildiği gibi, eğitmen de onlara sorularını ve yorumlarını aktarabilmektedir. Katılımcılarla yapılan görüşmelerden birinde "Eğitmenin sinıf içerisinde yazll ve sözlü olarak herkese anında geri bildirim verebilmesi güzeldi” diye bir yorum alınmıştır.

- Rahatça davranmalarına olanak sağlaması: Sanal dünya içerisinde katılımcılar sınıf ortamında bulunduklarından daha rahat hissetmişlerdir. Görüşmelerde "Arkadaşlarımız arasında birbirimizi iterek bile şakalaşmalar yaptık. Sinıf ortamında bu kadar rahat olamazdık." diye belirtilmiştir.

- Mekân bağımsızlığı sağlaması: Üniversite ile farklı bir semtte oturan katılımcılardan biri "Okul ortamına gitmemek hem zaman açısından hem de yorgunluk açısından avantajliydl." diye belirtmiştir.

- Uygulama sonrası sistemi kullanma isteği: Katılımcılar genel olarak eğitim döneminin bitmesinden sonra da sanal dünyaları kullanmak istediğini belirtmişlerdir. Katılımc1lardan bazıları "BÖTE sanal mezunlar toplantısl yapabilir miyiz?" diye sormuşlardır.

- Avatarların istenildiği gibi düzenlenebilmesi: Katılımcılar avatarlarını sunulan imkanlar kapsamında istediği gibi düzenleyebilmişlerdir. Buna bağlı olarak katılımcılardan bazıları "Karakterimin giyimini değiştirmek beni sisteme bağladı." diye söyleyerek sisteme olan memnuniyetlerini belirtmişlerdir.

Kullanıcı memnuniyetlerinin olumsuz yönde bulunduğu bulgular ise aşağıda yer alan kodlarla gösterilmektedir:

- Spor ve sosyal etkinliklerinin az olması: Sanal dünya içerisinde sportif aktivite olarak sadece futbol sahası bulunmaktadır. Grup görüşmelerinde katılımcılar "Futbol yerine satranç, voleybol $v b$. gibi sportif etkinlikler de eklenmeliydi." diye belirtmişlerdir. 
Sosyal aktivite olarak ise sadece kafeterya bulunmaktadır. Buna ek olarak katılımcıların çoğu grup görüşmeleri sırasında "Sinema salonu, konser salonu vb. etkinlikler bulunabilirdi." diyerek sosyal etkinliklerin az olduğunu da belirtmişlerdir.

- Sosyal etkinliklerin planlı olmaması: Sistemde eğitimsel aktivitelerin bir programı varken sosyal etkinliklerin bir planı bulunmamaktadır. Katılımcılardan biri "Etkinliklere katılmakta derslere katılmak gibi zorunlu olmallydı." diye belirtmiştir.

- Avatar seçeneklerinin az olması: Sanal dünya içerisinde üç adet avatar çeşitliliği bulunmaktadır. Katılımcilardan biri "Daha farklı karakterler olsaydı avatarımızı ona göre değişebilirdik ve benimseyebilirdik." diye belirmiştir. Diğer kullanıcıların konuyla ilgili görüşleri de benzer yöndedir.

- Avatarların insani özelliklerinin bulunmaması: Avatarların yorgunluk, uyku vb. insani özellikleri bulunmamaktadır. Katılımcılardan biri "Ĕger sanal dünya içerisinde insani özelliklere sahip bir karakterimiz olsayd daha çok zaman harcayabilirdik." diye eklemiştir.

\section{İşbirlikli öğrenmeyi destekleyen üç-boyutlu sanal öğrenme ortamlarının geliştirilmesi için kullanımı kolaylaştıran etkenler nelerdir?}

Görüşme ve anket içerisindeki açık uçlu sorular ile elde edilen bulgular içerik analizi yapılarak "Erişim ve İletişim", "Kullanılabilirlik", "Eğitim Ortamı" ve "Sanal Ortam" ana başlıkları altında incelenmiştir. Tablo 7'de ise sistemin kullanımını kolaylaştıran etkenlerin kod ve tema tablosu gösterilmektedir.

Tablo 7. Geliştirilen Sistemin Kullanımını Kolaylaştıran Etkenlerin Kod ve Tema Tablosu

\begin{tabular}{|c|c|c|}
\hline TEMA & 1. DÜZEY KOD & 2. DÜZEY KOD \\
\hline \multirow{3}{*}{ Erişim ve İletişim } & Sanal Dünyaya Erişim & $\begin{array}{l}\text { - İnternet alt yapısının uygun olmas } \\
\text { - Kurulum için dokümantasyonların } \\
\text { olması }\end{array}$ \\
\hline & Sanal Dünya içi Erişim & $\begin{array}{l}\text { Uçma, 1şınlanma, koşma gibi } \\
\text { özelliklerin olması } \\
\text { - Sistem içi haritaların detaylı } \\
\text { olması }\end{array}$ \\
\hline & İletişim & $\begin{array}{l}\text { - İletissim araçları açısından zengin } \\
\text { olması }\end{array}$ \\
\hline Kullanılabilirlik & Kullanılabilirlik & $\begin{array}{l}\text { - } \begin{array}{l}\text { Öğrenilebilir ve hatırlanabilir } \\
\text { olması }\end{array} \\
\text { - } \quad \begin{array}{l}\text { Sade ve anlaşılabilir bir tasarıma } \\
\text { sahip olması }\end{array} \\
\end{array}$ \\
\hline \multirow[t]{2}{*}{ Eğitim ortamı } & Eğitim/Öğretim & $\begin{array}{ll}\text { - } & \text { Örgün öğretime alternatif olması } \\
\text { - } & \text { Derse odaklanmayı arttırması } \\
\text { - } & \text { Zaman bağımsızlığı sağlaması } \\
\end{array}$ \\
\hline & Ortak Eğitim Alanları & - Konu anlatım ve proje sunum \\
\hline
\end{tabular}




\begin{tabular}{|c|c|c|}
\hline & & araçlarının olması \\
\hline & Grup Odaları & $\begin{array}{ll}\text { - } & \text { Mekân bağımsızlığı olması } \\
\text { - } & \text { Uygun eğitim araçlarının olması }\end{array}$ \\
\hline \multirow{3}{*}{ Sosyal Ortam } & \multirow[t]{2}{*}{ Sanal Dünya } & $\begin{array}{l}\text { - } \quad \text { Gerçekten yaşıyormuş hissi olması } \\
\text { - } \quad \text { Benzeri sistemlerden haberdar } \\
\text { olmalarını sağlaması }\end{array}$ \\
\hline & & $\begin{array}{l}\text { - Sistemi daha önce kullanmış } \\
\text { olması }\end{array}$ \\
\hline & Oryantasyon & $\begin{array}{l}\text { - Kullanımıyla ilgili eğitimlerin } \\
\text { olması }\end{array}$ \\
\hline
\end{tabular}

- Erişim ve İletişim (Öğrencilerin sanal dünyadaki erişimleri ve iletişimleri ile ilgili düşüncelerinin ve yaşadıklarının sınıflandırıldığı tema)

○ Sanal Dünyaya Erişim (Öğrencilerin sanal dünyaya erişimleri ile ilgili düşüncelerinin ve yaşadıklarının sınıflandırıldığı tema)

- İnternet alt yapısının uygun olması: $\mathrm{Bu}$ ortamlara erişim sağlanması aşamasında görsel ve işitsel materyallerin sorunsuzca yüklenebilmesi için internet bağlantısına ihtiyaç vardır. İnternet hizmetinin kalitesinin artması kullanım kalitesini daha da arttıracaktır. Görüşmelerde bir kullanıc1 "Internet hızım kampus ortamına erişimimi daha kolay hale getiriyor." diye belirtmiştir.

- Kurulum için dokümantasyonların olması: Yazılımın kurulum ile ilgili hazırlanan bilgilendirmelerin yapıldığı dokümanların katılımcıların işini kolaylaştırdığı ve süreci daha da hızlandırdığ sonucu ortaya çıkmıştır. Görüşmelerde bir kullanıcı "Kurulum yönergeleri sistemde büyük rahatllk sağladl." diye belirtmiştir.

○ Sanal Dünya içi Erişim (Öğrencilerin sanal dünya içerisindeki ortamlara erişimleri ile ilgili düşüncelerinin ve yaşadıklarının sınıflandırıldığı tema)

- Uçma, ışınlanma, koşma gibi özelliklerin olması: Sanal kampüs içerisine bulunan alanlara erişebilmek için katılımcıların kullandığ yöntemler "koşma, uçma, 1şınlanma" gibi özelliklerdir. Görüşmelerde gelen cevaplardan biri "Işınlanma ve uçma özelliği bize zaman kazandırdl." şeklindedir.

- Sistem içi haritaların detaylı olması: Katılımcıların haritadan gitmek istedikleri yeri bularak 1şınlanma yaptıkları gözlemlenmiştir aynı zamanda yorumlarında da katılımcilardan biri "Işınlanma kullanımı kolaylaştıran bir etkendi. Aynı zamanda haritalarda erişim kolaylığı să̆lıyordu." diye belirtmiştir. 
○ İletişim (Öğrencilerin sanal dünya içerisindeki kullanıcı-kullanıcı, kullanıc1eğitmen, kullanıcı-araçlar iletişim ve kullanıcı-kullanıcı, kullanıcı-eğitmen iletişimleri ile ilgili düşüncelerinin ve yaşadıklarının sınıflandırıldığı tema)

- İletişim araçları açısından zengin olması: Sistem içerisindeki katılımcıların yazılı ve sözlü olarak zengin iletişim imkânları bulunmaktadır. İletişim araçları senkron ve asenkron olmak üzere iki başlık altında toplanmıştır. Konuyla ilgili katılımcılar ile yapılan görüşmelerde "Başka yazılımlara gerek kalmadan sistemi kullanabildim" diye belirtilmiştir.

- Kullanılabilirlik (Öğrencilerin sanal dünyanın kullanılabilirliği ile ilgili düşüncelerinin ve yaşadıklarının sınıflandırıldığı tema)

- Öğrenilebilir ve hatırlanabilir olması: Katılımcılar sanal kampüsün ögrenilebilir ve hatırlatılabilir olduğundan bahsetmişlerdir. Odak grup görüşmelerinde katılımcılardan gelen cevap "Sanal kampüsü ilk kullandığım zaman biraz zorlanmıştım ama sonraki günlerde bu durum ortadan kalkt." şeklindedir. Katılımcıların tamamına yakını da benzer yönde cevaplar vermişlerdir.

- Sade, anlaşılabilir bir tasarıma sahip olması: $\mathrm{Bu}$ ortam bir okul ortamında olması gerektiren öğelerin dışında çok fazla ayrıntı içermemektedir. Bu sebeple "Sanal Kampüs" kullanıcılara sade bir tasarıma sahip gibi gelmiştir. Bu bağlamda katılımcılardan biri "Sanal kampüs içerisinde kaldırllması gereken bir öğe yoktur. Sistem yeterince sadedir." diye belirtmiştir.

- Eğitim Ortamı (Öğrencilerin sanal dünya içerisindeki eğitim ortamı öğeleri ile ilgili düşüncelerinin ve yaşadıklarının sınıflandırıldığı tema)

○ Ĕğitim/Öğretim (Öğrencilerin sanal dünya içerisindeki eğitim ve öğretim araçları ve ortamları ile ilgili düşüncelerinin ve yaşadıklarının sınıflandırıldığı tema).

- Örgün öğretime alternatif olması: Odak grup görüşmelerinde sanal kampüs ortamının örgün öğretim yerine kullanılabilir mi diye sorulduğunda kat1lımc1lardan biri "Yüz yüze eğitimin yerini dolduramaz ama ek materyal olarak kullanılabilir" diye belirtmiştir.

- Derse odaklanmayı arttırması: Fiziksel sınıf ortamındaki dezavantajlardan biri olan gürültü unsurlarının ev rahatlığında işlenen derslerde olmaması derse odaklanmayı kolaylaştırdığını katılımcılardan biri görüşmelerde "Sinıf kalabalık olduğundan dolayı sürekli dikkatimi dağıtan bir şey oluyordu." diye belirtmiştir.

- Zaman bağımsızlığı sağlaması: Sanal kampüs ile katılımcılar işbirliğine dayalı olan çalışmalarını istedikleri vakitte gerçekleştirebilmişlerdir. Grup görüşmelerinde "İstediğimiz zaman 
grup çalı̧̧ması yapabildik." diye belirtmiştir. Diğer katılımcılardan gelen cevaplar da benzer nitelikte olmuştur.

○ Ortak Ĕgitim Alanları (Öğrencilerin sanal dünya içerisinde konu anlatımlarını ve proje sunularını yaptıkları alanlarla ile ilgili düşüncelerinin ve yaşadıklarının sinıflandırıldığı tema)

- Konu anlatım ve proje sunum araçlarının olması: Sanal kampüs içerisinde eğitimler düzenlenirken düz anlatım yöntemi kullanılmasının yerine sistemde akıllı tahtaların kullanılması eğitimlere farklı bir bakış açısı katmıştır. Katılımcılardan biri görüşmelerde "Ders anlatımında sunumun tahtaya yüklenmesi güzel bir özellikti" diye belirtmiştir. Ortak eğitim alanlarında bulunan akıllı tahtalar aracıllğıyla sistem içerisinde kullanılabilecek bütün araçların görevleri yapılabilmektedir. Yine görüşmelerden birinde "Hem sunum hem de kavram haritamızı yükleyebilmemiz işimize yaradı" diye belirtilmiştir.

- Grup Odaları (Öğrencilerin sanal dünya içerisinde işbirliğine dayalı olarak grup çalışmalarını yaptıkları alanlarla ilgili düşüncelerinin ve yaşadıklarının sinıflandırıldığı tema)

- Mekân bağımsızlığı olması: Sanal dünyalar mekân bağımsızlığı sağlamaktadırlar. Önceleri grup çalışmaları için zaman ve mekân ayarlamaya çalışan katılımcılar süreç içerisinde sistemi kullanarak zaman ve mekândan kazanç sağlamıştır. Katılımcılardan biri odak grup görüşmelerinde "Zamandan ve mekândan bağımsız ders işleyebilmemizi sağladı" diye belirtmiştir.

- Uygun eğitim araçlarının olması: Sanal kampüs ortamı geliştirilirken işbirliğine dayalı materyallerin kullanıldığı diğer çalışmalar referans alınarak belirlenen işbirliğine dayalı ögrenme araçları kullanıcılar açısından faydalı bulunmuştur. Odak grup görüşmelerinde "Problem yaşamadığımız zaman araçlar sorunsuz olarak çalışmışt.." diye bir cevap alınmıştır.

- Sosyal Ortam (Öğrencilerin sanal dünya içerisindeki sosyal ortam öğeleri ile ilgili düşüncelerinin ve yaşadıklarının sınıflandırıldığı tema)

○ Sanal Dünya (Öğrencilerin sanal dünya öğeleriyle ilgili düşüncelerinin ve yaşadıklarının sınıflandırıldığı tema)

- Gerçekten yaşıyormuş hissi olması: Katılımcıların karşılarındaki kişilerin gerçek olduğunu bilmeleri sistemi gerçekten yaşıyormuş hissi yaratmıştır. Katılımcılardan biri "Sistemde kimsenin olmadĭ̆ durumlarda boş bir sokakta gerçekten yalnız yürüyormuş gibi düşünüyordum." diye belirtmiştir.

- Benzeri sistemlerden haberdar olmalarını sağlaması: Katılımcılar daha önceden sanal dünyaların isimlerini bilmesine rağmen kullanmaya imkân bulamamışlardır. Temel kullanım için eğitim alan katılımcılar 
“İlerleyen dönemlerde üst düzey kullanım için eğitim olacak mı?” diye sormuşlardır.

- Sistemi daha önceden kullanmış olması: Sanal dünyaları daha önceden kullanmış katılımcılar deneyimlerini diğer grup arkadaşlarıyla paylaşmışlardır. Katılımcılardan bazıları "Daha önceden sanal kampüsü kullanmış arkadaşlarım bana yardımcı oldu." diye belirtmişlerdir.

○ Oryantasyon: (Öğrencilerin sanal dünya içerisindeki ortamlara alışmaları süreci ve sanal ortamların kullanımını öğrenmeleriyle ilgili düşüncelerinin ve yaşadıklarının sınıflandırıldığı tema)

- Kullanımıyla ilgili eğitimlerin olması: Sanal kampüs kullanımına başlamadan önce katılımcılara sistemin kullanımıyla ilgili bir eğitim verilmiştir. Katılımc1lardan biri odak grup görüşmesinde "ilk verilen eğitimin sanal kampüsü keşfetmeme imkân sağladl." diye belirtmiştir. Benzer yorumlar diğer verilerde de bulunmaktadır.

\section{İşbirlikli öğrenmeyi destekleyen üç-boyutlu sanal öğrenme ortamlarının geliştirilmesi için kolay kullanımı engelleyen etkenler nelerdir?}

Görüşme ve anket içerisindeki açık uçlu sorular ile elde edilen bulgular içerik analizi yapılarak "Erişim ve İletişim", "Kullanılabilirlik", "Eğitim Ortamı" ve "Sanal Ortam" ana başlıkları altında incelenmiştir. Tablo 8'de ise sistemin kullanımını engelleyen etkenlerin kod ve tema tablosu gösterilmektedir.

Tablo 8. Geliştirilen Sistemin Kullanımını Engelleyen Etkenlerin Kod ve Tema Tablosu

\begin{tabular}{|c|c|c|}
\hline TEMA & 1. DÜZEY KOD & 2. DÜZEY KOD \\
\hline \multirow[t]{3}{*}{ Erişim ve İletişim } & Sanal Dünyaya Erişim & $\begin{array}{l}\text { - } \quad \text { IP adresinin değişmesi } \\
\text { - } \quad \text { Tablet PC'yle erişim hakkında } \\
\text { dokümantasyonların bulunmaması } \\
\text { - } \quad \text { Donanım eksikliğinin bulunması }\end{array}$ \\
\hline & Sanal Dünya içi Erişim & $\begin{array}{l}\text { - Grup odalarına direk erişim } \\
\text { bulunmaması }\end{array}$ \\
\hline & İletişim & $\begin{array}{l}\text { - Aktiflik durumunu kontrol eden } \\
\text { sistemin olmaması }\end{array}$ \\
\hline Kullanılabilirlik & Kullanılabilirlik & $\begin{array}{ll}\text { - } & \text { Şifre değiştirme panelinin } \\
\text { olmaması } \\
\text { - } & \text { Gizlilik ayarlarının olmaması } \\
\text { - } & \begin{array}{l}\text { Başlangıç noktasının belirlenmiş } \\
\text { olması }\end{array} \\
\text { - } & \begin{array}{l}\text { Bazı mimari yapıların tasarımsal } \\
\text { problemleri }\end{array} \\
\text { - } & \text { Gece/gündüz kavramının sıklıkla } \\
\end{array}$ \\
\hline
\end{tabular}




\begin{tabular}{|c|c|c|}
\hline & & değişmesi \\
\hline \multirow{4}{*}{ Eğitim ortamı } & \multirow{3}{*}{ Eğitim/Öğretim } & $\begin{array}{l}\text { - } \quad \text { Eğitsel araçların bazı } \\
\text { sinırlılıklarının bulunması }\end{array}$ \\
\hline & & - Derslerin kayıt altına alınmaması \\
\hline & & $\begin{array}{l}\text { - Ortak paylaşım havuzunun } \\
\text { bulunmaması }\end{array}$ \\
\hline & Grup Odaları & $\begin{array}{l}\text { - Gizlilik ve veri güvenliği } \\
\text { bulunmaması }\end{array}$ \\
\hline \multirow{2}{*}{ Sosyal Ortam } & Sanal Dünya & - Oyun hissi yaratmasi \\
\hline & Oryantasyon & $\begin{array}{l}\text { - "Sikça sorulan sorular" panelinin } \\
\text { bulunmaması }\end{array}$ \\
\hline
\end{tabular}

- Erişim ve İletişim (Öğrencilerin sanal dünyadaki erişimleri ve iletişim ile ilgili düşüncelerinin ve yaşadıklarının sınıflandırıldığı tema)

○ Sanal Dünyaya Erişim (Öğrencilerin sanal dünyaya erişimleri ile ilgili düşüncelerinin ve yaşadıklarının sınıflandırıldığı tema)

- IP adresinin değişmesi: Süreç içerisinde zorunlu olarak 3 kere IP adresi değiştirilmiştir. Katılımcılarla yapılan görüşmelerde "IP adreslerinin değişmesi sistemin bozulduğunu düşünmeme sebep oldu." diye bir görüş alınmıştır.

- Tablet PC'yle erişim hakkında dokümantasyonların bulunmaması: Hazırlanan dokümantasyonlar sadece PC içindir. Katılımcılardan bazıları "OpenSim tablet ile çalışıyor mu?" diye sormuştur.

- Donanım eksikliğinin bulunması: Sanal dünyalara bağlanabilmek için teknolojik açıdan iyi bir durumda olan bilgisayara sahip olmak gereklidir. Katılımcılardan biri "Bilgisayarımın grafik kartı yeterli gelmediğinden sistem takılmalar yapmıştır." diye görüş belirtmiştir. Diğer kullanıcıların benzer problemler yaşadıkları da görüşmeler sırasında anlaşılmıştır.

○ Sanal Dünya içi Erişim (Öğrencilerin sanal dünya içerisindeki ortamlara erişimleri ile ilgili düşüncelerinin ve yaşadıklarının sınıflandırıldığı tema)

- Grup odalarına direk erişim bulunmaması: Sanal kampüs içerisinde grup odalarına erişim uçarak, haritadan ışınlanarak veya arkadaşların tarafindan 1şınlanarak gerçekleştirilmektedir. Katılımcılardan "Işınlanma noktalarının olması daha kullanışlı olurdu." ve "Zamandan daha fazla tasarruf ederdik." diye yorumlar gelmiştir.

○ İletişim (Öğrencilerin sanal dünya içerisindeki kullanıcı-kullanıcı, kullanıc1eğitmen, kullanıcı-araçlar iletişimleri ve kullanıcı-kullanıcı, kullanıcı-eğitmen iletişimleri ile ilgili düşüncelerinin ve yaşadıklarının sınıflandırıldığı tema)

- Aktiflik durumunu kontrol eden sistemin olmaması: Sistem içerisinde katılımcılardan bazılarının sınıf alanındaki sandalyeye 
oturarak bilgisayar başından kalktığı veya başka şeylerle ilgilendiği fark edilmiştir. Katılımcılardan biri görüşme sırasında "Dersi birlikte aldı̆̆ımız arkadaşlarımızın sistemde olup olmadı̆̆ bulan bir geri bildirim sistemi belirlemeliyiz." diye belirtmiştir. Diğer katılımcıların da benzer düşüncede olduğu görüşmelerden gözlemlenmiştir.

- Kullanılabilirlik (Öğrencilerin sanal dünyanın kullanılabilirliği ile ilgili düşüncelerinin ve yaşadıklarının sınıflandırıldığı tema)

- Şifre değiştirme panelinin olmaması: Katılımcılara sürecin başlangıcında bir şifre gönderilmiştir. Katılımcılar görüşmelerde "Şifremi değiştir panelini bulamadım." diye belirtmişlerdir.

- Gizlilik ayarlarının olmaması: Sanal kampüs içerisinde kimlik gizliliği özelliği bulunmamaktadır. Grup görüşmelerinde "Kendimle ilgili bazı bilgileri gizleyebilmeliyim." diye geri bildirim gelmiştir.

- Başlangıç noktasının belirlenmiş olması: Sisteme her giriş yapıldığında önceden belirtilen bir başlangıç noktasına erişim sağlanmaktadır. Katılımcılardan biri "Sanal kampüsten düştügüm zaman sınıf alanına ışılanmam zaman alıyordu." diye belirtmiştir. Diğer katılımcıların görüşleri de benzer yöndedir.

- Bazı mimari yapıların tasarımsal problemleri: Bazı yapıların merdivenlerinde tasarımsal olarak hatalar tespit edilmiştir. Kat1lımc1lardan biri "Oditoryum alanındaki merdivenler kullanılmadı̆̆ından uçmak zorunda kaldım." diye belirtmiştir. Aynı problemi yaşayan diğer kullanıcıların da bu konuyla ilgili farklı çözümler bulduğu anlaşılmıştır.

- Gece/gündüz kavramının sıklıkla değişmesi: Katılımcılar sistem içerisinde bölge değiştirdiklerinde sistemdeki saat dilimi değişmektedir. Kat1lımcilardan bir tanesi "Sistemin bir anda gece olması ders dinlerken dikkatimi dağıtıyordu." diye belirtmiştir.

- Eğitim Ortamı (Öğrencilerin sanal dünya içerisindeki eğitim ortamı öğeleri ile ilgili düşüncelerinin ve yaşadıklarının sınıflandırıldığı tema)

○ Eğitim/Öğretim (Öğrencilerin sanal dünya içerisindeki eğitim ve öğretim araçları ve ortamları ile ilgili düşüncelerinin ve yaşadıklarının sınıflandırıldı $\breve{g}_{1}$ tema).

- Eğitsel araçların bazı sınırlılıklarının bulunması: Sanal kampüs içerisindeki eğitim/öğretim araçları "Google Documents" gibi ücretsiz lisans kullanım hakkı olan araçlardan oluşmaktadır. Katılımcılardan biri "Google Doc. fazla kişi sisteme bağlandı̆̆ında problem çıkarlyordu." diye belirtmiştir. $\mathrm{Bu}$ yorum diğer görüşmelerdeki katılımcıların görüşleriyle de benzerlik göstermektedir. Katılımcılar bu konuyla ilgili genel olarak ücretli lisanslı yazılımların kullanılmasına yönelik önerilerde bulunmuşlardır. 
- Derslerin kayıt altına alınmaması: Oditoryumda yapılan dersler kayıt altına alınmamıştır. Katılımcılardan biri "Yaptığımız dersler diğer uzaktan eğitim uygulamaları gibi kayıt altına alınmalıydı." diye belirtmiştir.

- Ortak paylaşım havuzunun bulunmaması: Sanal kampüs katılımcıları kendi arkadaşları arasında paylaşım yapabilecekleri araçları aramışlardır. "Kampüs Defteri" bu amaçla kullanılmasına rağmen katılımcılar tarafından yeterli bulunmamıştır. Katılımcılardan biri "Yaptığım projemi sanal kampüse yükleyebileceğim ve istediğim zaman arkadaşlarımla paylaşabileceğim bir araç bulunmamaktadır." diye belirtmiştir.

○ Grup Odaları (Öğrencilerin sanal dünya içerisinde işbirliğine dayalı olarak grup çalışmalarını yaptıkları alanlarla ilgili düşüncelerinin ve yaşadıklarının sinıflandırıldığı tema)

- Gizlilik ve veri güvenliği bulunmaması: Sanal kampüs içerisinde şifreli özel alan özelliği bulunmamaktadır. Katılımcılar görüşmelerde "Grup odalarımıza sadece grup üyeleri girmeliydi." diye belirtmişlerdir.

- Sosyal Ortam (Öğrencilerin sanal dünya içerisindeki sosyal ortam öğeleri ile ilgili düşüncelerinin ve yaşadıklarının sınıflandırıldığı tema)

○ Sanal Dünya (Öğrencilerin sanal dünya öğeleriyle ilgili düşüncelerinin ve yaşadıklarının sınıflandırıldığı tema)

- Oyun hissi yaratması: Sanal kampüs ortamı x, y, z uzayı içerisinde çizime dayalı bir ortamdır. Katılımcılara sanal dünyalar bundan dolayı oyun gibi gelmektedir. Katılımcılardan bir tanesi "Sanal kampüse girdiğimde oyun oynuyormuşum gibi hissediyorum." diye belirtmiştir. Görüşme sırasında diğer kullanıcılar da benzer bir fikir beyan etmiştir.

○ Oryantasyon: (Öğrencilerin sanal dünya içerisindeki ortamlara alışmaları süreci ve sanal ortamların kullanımını öğrenmeleriyle ilgili düşüncelerinin ve yaşadıklarının sınıflandırıldığı tema)

- "Sıkça sorulan sorular" panelinin bulunmaması: Katılımcılar ortamla ilgili problemleri olduğunda sanal kampüs içerisinden "Kampüs Defterini” doldurmuşlardır. Görüşmelerde katılımcılardan biri "Kampüs defteri yerine problemlerimizi bildirmek için bir Forum sayfası kurulabilirdi." diye belirtmiştir. Diğer katılımcılar da ilgili fikri desteklemiştir.

\section{Tartışma, Sonuç ve Öneriler}

Yapılan araştırmalar teknoloji destekli eğitimlerin, etkililiğinin ve verimliliğinin artması için doğru materyallerin seçilmesi ve tasarım süreçlerinde bir alt yapının bulunması gerektiğini söylemektedir (Barab ve diğerleri, 2004; Barab, ve diğerleri, 2005; Dillenbourg ve diğerleri, 
2002; Gütl, Chang, Kopeinik ve Williams, 2009; Gresalfi, Rittle-Johnson, Loehr ve Nichols, 2018; Salmon, 2009). Aynı zamanda benzeri araştırmalarda, geliştirilen sistemlerin tasarım seçimlerinden kaynaklı olarak olumlu çıktılar oluşturmasına rağmen tasarımsal farklılıklarından kaynaklı olarak farklı çıktılara sahip olduğu da aktarılmıştır (Gresalfi ve diğerleri, 2018; Yılmaz ve Cagiltay, 2016). Üç-boyutlu sanal dünyalar öğrenme ortamı olarak kullanıldığında teknolojik imkânlarından kaynaklı olarak katılımcılara bir takım faydalar sağlamaktadır. Bunlardan bazıları; zengin öğretim araçları sunması, farklı senaryolara ve eğitimlere uygun olması, eğitimde özerklik sağlaması, eğitimde imkânları arttırması, katılımcıların tutum, öz yeterlilik, sosyal bulunuşluk ve motivasyonunu olumlu olarak etkilemesi, kullanıcılar arasında iletişimi ve etkileşimi arttırması gibi bileşenlerden oluşmaktadır (Dillenbourg, ve diğerleri, 2002; Scheucher, Bailey ve Gütl, 2009; Horzum, 2015; Minocha ve Hardy, 2016; Tüzün ve Özdinç, 2010; Warburton, 2009). Sanal teknolojilerin eğitime entegrasyonunda uygulanan vizyon günümüzde dahil net olmamasından kaynaklı olarak bu sistemlerin tasarımlarında etkili öğretim tasarımlarının kullanılması önemlidir (Martín-Gutiérrez, Mora, Añorbe-Díaz ve GonzálezMarrero, 2017). Başka bir ifadeyle üç-boyutlu sanal öğrenme ortamlarının faydaların ortaya çıkması amacıyla geliştirilen sistemin etkililiğini ve verimliliğini arttırmak için tasarım süreçlerinin dikkatli bir şekilde tamamlanması gerekmektedir. $\mathrm{Bu}$ bağlamda araştırma kapsamında geliştirilen işbirlikli öğrenmeyi destekleyen üç-boyutlu sanal öğrenme ortamı da, sanal dünyaların eğitim ortamı olarak kullanıldığında sağladığı faydalardan birçoğunu bulundurduğu elde edilen bulgularda görülmüştür. Bu bulgular kapsamında geliştirilen sistemde etkililiğin ve verimliliğin sağlanması için başta kullanıcıların sosyal buradalık hissinin ve motivasyonunun sağlanması gerektiği, buna ek olarak sanal dünyaların sistem içi problem çözümlerinin kolay olması, zaman ve/veya mekan özgürlügünün sağlanması gibi etkenlerin sistem kullanışlılığını ve bunun yanı sıra dolaylı olarak da kullanıcı motivasyonun artmasına imkan sağlayabilecek sonuçlar ortaya çıkmıştır.

Üç-boyutlu sanal öğrenme ortamları katılımcılarda gerçeklik hissi oluşturan ve ortam ögeleriyle etkileşimi sağlayan eğitsel amaçla kullanılan sistemler olarak tanımlanmıştır (Dillenbourg, ve diğerleri, 2002; Minocha ve Hardy, 2016; Scheucher, Bailey ve Gütl, 2009). $\mathrm{Bu}$ bağlamda geliştirilen bu ortam, taşıdığ sosyal bulunuşluk hissi, başka bir deyişle ortamda gerçekten bulunma hissi yaratmaktadır. Bu hissin oluşmasının nedenleri elde edilen bulgulardan yola çıkıldığında kullanıcıların birer avatarının olması, ortam içerisinde gerçek dünya öğelerinin bulunması, diğer kullanıcıların gerçek bireyler olduğunun bilinmesi, etkileşim imkanları gibi nedenleri içermektedir. Alan yazında sosyal bulunuşluk ile ilgili olan tanımlamalarda da kullanıcı kontrolündeki avatar, etkileşim imkânı, üç-boyutlu ses teknolojisi vb. özelliklerin bu hissi olumlu yönde arttırdığından bahsedilmiştir (Dass ve diğerleri, 2011; Dillenbourg ve diğerleri, 2002; Minocha ve Hardy, 2016; Yılmaz ve diğerleri, 2015). Bu tanımlamadan yola çıkılarak sosyal bulunuşluk ile elde edilen bulguların alan yazınla benzer yönde olduğu görülmektedir. $\mathrm{Bu}$ bağlamda sanal dünyaların öğretim ortamı olarak tasarlanması sürecinde geliştirilen sistemin gerçek hayat benzerlik seviyesi, avatarların kişiselleştirilme imkânı, sistem içindeki etkileşim ve iletişim araçlarının çeşitliliği sistem kullanıcılarının sosyal bulunuşluğuna doğrudan etki eden bileşenler olduğu söylenebilir.

Bulgular doğrultusunda elde edilen diğer sonuçlar ise işbirlikli öğrenmeyi destekleyen üçboyutlu sanal öğrenme ortamını kullanan katılımcıların eğitime odaklanma ve aktif olarak bu 
ortamlara katılmasına katkı sağladığ 1 yönündedir. Motivasyon ile ilgili olan aktif katılım ve odaklanma bileşenleri, alan yazında bulunan araştırmalarda da sanal ortamların eğitim amaciyla kullanılmasının katılımcı motivasyonunu arttırıcı yönde sonuçları olduğunu göstermiştir (Dalgarno ve Lee, 2010; Stone ve diğerleri, 2011; Tüzün, 2010). Elde edilen bulgular kapsamında motivasyonu etkileyen faktörlerin teknik desteğin ve geri bildirimlerin zamanlanması, bilişsel yükün derecesi, eğitimdeki esneklik seviyesi vb. bileşenlerdeki farklılıklar olduğu görülmüştür. Eğitimdeki esneklik seviyesiyle ilgili alan yazında zamanmekan bağımsızlı̆̆ının ve asenkron eğitim imkanlarının yarattığı esnekliğin kullanıcılarda olumlu yönde motivasyon değişikliğine neden olduğu sonuçları görülmüştür (Tüzün ve Özdinç, 2010; Warburton, 2009). Uygulama sürecinde katılımcıların sistem ile yaşadığı problemlerin en kısa sürede çözülmesi bu ortamların sınırlılığını azalttığı sonucu alan yazında görülmüştür ve katılımciların motivasyonuna olumlu yönde etkide bulunmuştur (Eaton, Guerra, Corliss ve Jarmon, 2011; Gül, 2011; Horton, 2000). Araştırma bulgularından elde edilen sonuçların en kısa zamanda çözülmüş olması bulguların alan yazındaki sonuçlara benzer olduğunun bir göstergesidir.

Memnuniyet ve motivasyona yönelik yapılan bir çalışmada e-öğrenme hazırlığ bilgisayar öz yeterliği, internet öz yeterliği, çevrimiçi iletişim öz yeterliği, öz yönetimli öğrenme, öğrenen kontrolü ve e-öğrenmeye yönelik motivasyonun öğrenci memnuniyeti ve motivasyonunun belirleyici faktörler olduğu sonucu ortaya çıkmıştır (Yılmaz, 2017). Bulgulardan elde edilen sonuçlardan yol çıkıldığında katılımcıların geliştirilen üç-boyutlu sanal öğrenme ortamı içerisindeki kontrol ve iletişim özgürlügünün memnuniyet durumlarına ilişkin görüşüne olumlu yönde etki ettiği görülmektedir. Aynı zamanda öğrencilerin kontrol edemediği konularla ilgili olan sınırlılıklarda da memnuniyet durumlarına ilişkin görüşlerinin olumsuz yönde olduğu görülmüştür. Sanal öğrenme ortamlarında öğrenci memnuniyet seviyesine yönelik yapılan bir başka araştırmada ise geribildirimin katılımcıların memnuniyet seviyelerinde olumlu yönde sonuçları olduğu görülmüştür. (de Boer, Lagerweij, de Vries, Wesselink, ve Vervoorn, 2017). Bu durum yapılan araştırmada da katılımcıların eğitim araçlarından anında geribildirim alabilmesinin memnuniyet durumlarına ilişkin görüşü açısından olumlu yönde olduğu şekilde çıkmıştır.

Geliştirilen ortamın kullanılabilirliği katılımcılardan elde edilen bulgular kapsamında yüksek olarak değerlendirilmiştir. Bu bulgulardan bazıları; kurulum ve kullanım yönergelerinin bulunması, geliştirilen üç-boyutlu sanal dünyanın tasarımsal açıdan sade, öğrenilebilir ve hatırlanabilir olması olarak belirtilmiştir. Sistemin kurulumu ve kullanımıyla ilgili katılımcılara verilen dokümantasyonların dışında sistemin kullanımıyla ilgili yapılan oryantasyon süreci uygulamanın kullanımını daha da kolaylaştırmıştır. Alan yazında yapılan çalışmada da benzeri sistemlerin kullanımlarıyla ilgili yönergelerin hazırlanmış olması kolay kullanıma imkân sağlayan sistemlerin gelişmesini sağlamıştır (Schmeil ve Eppler, 2008). Aynı zamanda bir başka araştırmada da kurulum kolaylığı, erişim kolaylığı, arayüzün sadeliği, yardım imkanı, avatarların kontrolü, vb kriterler üç-boyutlu sanal öğrenme ortamının kullanılabilirliğinin değerlendirme kriteri olarak belirlenmiştir (Yılmaz, Reisoğlu, Topu, Karakuş ve Göktaş, 2015). Elde edilen bulguların bu sistemlerin kullanılabilirliğine yönelik değerlendirme kriterlerine benzerliği bu bulguların geçerliliğinin bir kanıtı niteliğinde olduğu olarak düşünülebilir. 
Sanal dünya içerisinde gece/gündüz kavramının sürekli değişmesi katılımcılarda bilişsel yükün artmasına ve motivasyon düşüklüğüne yol açmıştır. Elde edilen bulgular sistemin öğrenilme kolaylığı seviyesinin yüksek olmasının birkaç kullanımdan sonra bilinen problemden oluşabilecek olumsuzlukları en aza indirildiği sonucunu ortaya çıkarmıştır. Bilişsel yükü azaltmayı hedefleyen çözüm önerilerinden biri olarak önceden haber verme durumunun bilişsel yükün azalmasında etkili olduğu söylenen dokuz adımdan biri olduğu alan yazında bulunmaktadır (Mayer ve Moreno, 2003). Kullanım yönergelerinin hazırlanmasıyla elde edilen sonuçların alan yazına benzer yönde olduğu görülebilmektedir.

Sonuç olarak sanal ortamlarının eğitim amaçlı kullanımında etkililiğin ve verimliliğin sağlanabilmesi için sosyal bulunuşluluk, motivasyon ve kullanılabilirlik bileşenlerinin seviyeleri tasarım sürecinde doğru olarak tespit edilip geliştirilme işlemine başlanması gerekmektedir. Konuyla ilgili gelecekte yapılabilecek olan benzer çalışmalar için araştırmacılara yönelik öneriler aşağıdaki gibidir:

- Mesleki eğitim, beden eğitimi ve fizik tedavi uygulamalarıyla ilgili psiko-motor beceri gerektiren konularda verilen teorik eğitimlerin doğru uygulanmasına yönelik çalışmalar yapilabilir.

- Birbirini daha önceden tanımayan kişiler geliştirilen sanal ortama alınarak sanal ortam tekrardan test edilebilir.

- Geliştirilen sanal ortamda yarı deneysel çalışmalar yapılarak ortamın geleneksel eğitimle karşılaştırılması yapılabilir.

- Geliştirilen sanal ortamın memnuniyet seviyesi karşılaştırılmasına yönelik deneysel çalışmalar yapılabilir.

İşbirlikli Öğrenmeyi Destekleyen Üç-Boyutlu Sanal Öğrenme Ortamı Geliştirilmesi: Bir Durum Çalışması başlıklı çalışmanın yazım sürecinde bilimsel, etik ve alıntı kurallarına uyulmuş; toplanan veriler üzerinde herhangi bir tahrifat yapılmamış, karşılaşılacak tüm etik ihlallerde "Pamukkale Üniversitesi Eğitim Fakültesi Dergisi Yayın Kurulunun" hiçbir sorumluluğunun olmadığı, tüm sorumluluğun Sorumlu Yazara ait olduğu ve bu çalışmanın herhangi başka bir akademik yayın ortamına değerlendirme için gönderilmemiş olduğunu taahhüt ederim. 


\section{Kaynakça}

Barab, S., A., Kling, R., \& Gray, J., H. (Editörler) (2004). Designing for Virtual Communities in the Service of Learning. New York: Cambridge University Press.

Barab, S., Thomas, M., Dodge, T., Carteaux, R., \& Tuzun, H. (2005). Making learning fun: Quest Atlantis, a game without guns. Educational Technology Research and Development, 53(1), 86107.

Bower, M., Lee, M. J., \& Dalgarno, B. (2017). Collaborative learning across physical and virtual worlds: Factors supporting and constraining learners in a blended reality environment. British Journal of Educational Technology, 48(2), 407-430.

Can, T. (2012). Yabancı dil öğretimi bağlamında öğrenen özerkliginin sanal ögrenme ortamları yoluyla desteklenmesi. Hasan Ali Yücel Egitim Fakültesi Dergisi, 17(1), 72-85.

Chen, H. C. (2017). On the Creative Design of Amphibious Vehicles in a 3D Virtual Classroom Using OpenSim. International Journal of Information and Education Technology, 7(7).

Çoban, M., ve Göktaş, Y. (2013). Üç Boyutlu Sanal Dünyalarda Öğretim Materyalleri Geliştiren Tasarımcıların Karşılaştıkları Sorunlar. Mersin Üniversitesi Eğitim Fakültesi Dergisi, 9(2), 275287.

Dalgarno, B., \& Lee, M. J. W. (2010). What are the learning affordances of 3D virtual environments?. British Journal of Educational Technology, 40(1), 10-32.

Dalgarno, B., Gregory, S., Reiners, T., \& Knox, V. (2016). Practising teaching using virtual classroom role plays. Australian Journal of Teacher Education, 41(1), 126-154.

Dass, S., Dabbagh, N, \& Clark, K. (2011). Using virtual worlds: What the research says. The Quarterly Review of Distance Education, 12(2), 95-111.

de Boer, I. R., Lagerweij, M. D., de Vries, M. W., Wesselink, P. R., \& Vervoorn, J. M. (2017). The effect of force feedback in a virtual learning environment on the performance and satisfaction of dental students. Simulation in Healthcare, 12(2), 83-90.

Dillenbourg. P., Schneider, D., K., \& Synteta, P. (2002). Virtual learning enviroments. 3rd Hellenic Conference"Information and Communication Technologies in Education”' da sunuldu, Rhodes, Greece.

Duffy, T., \& Cunningham, D. (1996). Constructivism: Implications for the design and delivery of instruction. Handbook of research for educational communications and technology, New York: Macmillan.

Eaton, L. J., Guerra, M., Corliss, S., \& Jarmon, L. (2011). A statewide university system (16 campuses) creates collaborative learning communities in Second Life. Educational Media International, 48(1), 43-53.

Franczak, I. B. (2018). Is The Montessori Method A Solution To Improve Public Education? Comparing Two Pedagogical Models In Urban Schools.

Garrison, D. R., Anderson, T., \& Archer, W. (1999). Critical inquiry in a text-based environment: Computer conferencing in higher education. The internet and higher education, 2(2-3), 87-105.

Gresalfi, M. S., Rittle-Johnson, B., Loehr, A., \& Nichols, I. (2018). Design matters: explorations of content and design in fraction games. Educational Technology Research and Development, 66(3), 579-596.

Gül, L., F. (2011). İşbirlikli mimari tasarım eğitiminde sanal dünya kullanımı. Middle East Technical University Journal of the Faculty of Architecture, 28(2), 255-267.

Gütl, C., Chang, V., Kopeinik, S. \& Williams, R. (2009, September). 3d virtual worlds as a tool for collaborative learning settings in geographically dispersed environments. Conference ICL2009 da sunuldu, Villach. 
Horton, W. K. (2000). Designing web-based training: How to teach anyone anything anywhere anytime (Vol. 1). New York, NY: Wiley.

Horzum, M. B. (2015). Interaction, Structure, Social Presence, and Satisfaction in Online Learning. Eurasia Journal of Mathematics, Science \& Technology Education, 11(3).

Hu, Z., Cai, Z., \& Wen, C. (2018). The Application and Development of Virtual Reality-related Technology. Information Engineering and Applied Computing.

Huvila, I. (2018). Taking excavation to a virtual world: importing archaeological spatial data to Second Life and OpenSim. Uppsala.

Jones, G., \& Alba, A. D. (2019). Reviewing the effectiveness and learning outcomes of a 3D virtual museum: A pilot study. In Virtual Reality in Education: Breakthroughs in Research and Practice (pp. 52-75). IGI Global.

Karagiorgi, Y., \& Symeou, L. (2005). Translating Constructivism into Instructional Design: Potential and Limitations. Educational Technology and Society, 8(1), 17-27.

Koçak, Ö., Demirel, T., Yılmaz, T. K., ve Göktaş, Y. (2016). Sanal Dünyalarda Kullanılan Öğretim Stratejileri, Yöntemleri ve Teknikleri. e-Kafkas Ĕgitim Araştırmaları Dergisi, 3(2), 40-51.

Korucu, A. T., ve Çakır, H. (2015). Dinamik Web Teknolojileri İle Geliştirilen İşbirlikli Öğrenme Ortamını Kullanan Öğretmen Adaylarının Görüşleri. Adıyaman Üniversitesi Sosyal Bilimler Enstitüsü Dergisi, 8(19), 221-254.

Küfrevioğlu, R. M., Topu, F. B., Çoban, M., ve Göktaş, Y. (2012). 3 boyutlu sanal dünyalarda buradalık ve sosyal buradalık. 4. Ulusal Illköğretim Bölümleri Öğrenci Kongresi, (370-378. ss), Ankara: Nobel Yayın Dağıtım

Lowenthal, P., \& Mulder, D. (2017). Social presence and communication technologies. Social presence in online learning: Multiple perspectives on practice and research. Sterling, VA: Stylus.

Martín-Gutiérrez, J., Mora, C. E., Añorbe-Díaz, B., \& González-Marrero, A. (2017). Virtual technologies trends in education. EURASIA Journal of Mathematics Science and Technology Education, 13(2), 469-486.

Mayer, R. E., \& Moreno, R. (2003). Nine ways to reduce cognitive load in multimedia learning. Educational psychologist, 38(1), 43-52.

Minocha, S., \& Hardy, C. (2016). Navigation and wayfinding in learning spaces in 3D virtual worlds. Learning in Virtual Worlds: Research and Applications, 3-41.

Öztürk, E., ve Deryakulu, D. (2011). Çevrimiçi öğrenme topluluklarında iletişim aracı türünün bilişsel ve toplumsal buradalık üzerindeki etkisi. Hacettepe Üniversitesi Eğitim Fakültesi Dergisi, 41, 349359.

Reigeluth, C.M., \& Frick, T. (1999). Formative research: A methodology for improving design theories. In C.M. Reigeluth (Ed.), Instructional-design theories and models, Volume 2: A new paradigm of instructional theory (pp. 633-651). Mahwah, NJ:Erlbaum.

Rodriguez, A. L., Santiago, J. A. B., ve Covarrubias, D. A. C. (2016, April). Avatars and 3D virtual worlds for higher education at the University of Guadalajara, Mexico. International Academic Conferences'da sunuldu.

Salmon, G. (2009). The future for (second) life and learning. British Journal of Educational Technology, 40(3), 526-538.

Salmon, G., Nie, M., \& Edirisingha, P. (2010). Developing a five-stage model of learning in Second Life. Educational Research, (52), 169-182.

Savva, S. (2016). Re-imagining schooling: Weaving the picture of school as an affinity space for twentyfirst century through a multiliteracies lens. In Reimagining the purpose of schools and educational organisations (pp. 49-64). Springer, Cham. 
Scheucher, T., Bailey, P., H., Gütl, C., \& Harward, V., J. (2009). Collaborative virtual 3d environment for internet-accessible physics experiments. International Journal of Online Engineering, 5(1), 61-71.

Schillewaert, N., \& Meulemeester, P. (2005). Comparing Response Distributions of Offline and Online. International Journal of Market Research, 47(2), 163-178.

Schmeil, A., \& Eppler, M., J. (2008) Knowledge sharing and collaborative learning in Second Life: A classification of virtual 3d group interaction sripts. Journal of Universal Computer Science, 14(3), $665-677$

Stone, K., Polycarpou, I., Krause, J., \& Rader, C. (2011). Electronic Collaborative Learning in Math-City. International Conference on Frontiers in Education: Computer Science and Computer Engineering, pp. 295-301.

Tan, J. \& Jones, M. (2008, Ekim). An Evaluation of Tools Supporting Enhanced Student Collaboration. 38th ASEE/IEEE Frontiers in Education Conference 'nda sunuldu, Saratoga Springs, NY.

Tu, C. H., \& McIsaac, M. (2002). The relationship of social presence and interaction in online classes. The American journal of distance education, 16(3), 131-150.

Tüzün, H. (2010). Dünya üzerine yayılmış çok-kullanıcılı çevrim-içi eğitsel bir bilgisayar oyununun teknik yapısı ve Türkiye'de yaklaşımlar. G. T. Yamamota, U. Demiray, M. Kesim (Editörler). Türkiye'de E-Öğrenme Gelişmeler ve Uygulamalar. Ankara, ss. 261-281.

Tüzün, H., ve Özdinç, F. (2010, Şubat). 3-Boyutlu sanal üniversite oryantasyon ortamının geliştirilmesi. Akademik Bilişim'10 da sunuldu, Muğla.

United Nations. (2015). Transforming our world: The 2030 agenda for sustainable development. Resolution adopted by the General Assembly.

Wang, C. P., Lan, Y. J., Tseng, W. T., Lin, Y. T. R., \& Gupta, K. C. L. (2019). On the effects of 3D virtual worlds in language learning-a meta-analysis. Computer Assisted Language Learning, 1-25.

Wang, C., Lefaiver, M., Wang, Q., \& Hunt, C. (2011). Teaching in an EFL program in second life: Student teachers' perspectives and implications. Journal of Educational Technology Development and Exchange, 4(1), 27-40.

Warburton, S. (2009). Second Life in higher education: Assessing the potential for and the barriers to deploying virtual worlds in learning and teaching. British Journal of Educational Technology, 40(3), 414-426.

Wei, Y., Huang, L., Wang, W., Zhang, Y., \& Wang, Z. (2018, October). The Behavior Symptoms of Undergraduates' Social Anxiety in the Virtual World. In 2018 International Conference on Cyberworlds (CW) (pp. 447-450). IEEE.

Yilmaz, R. (2017). Exploring the role of e-learning readiness on student satisfaction and motivation in flipped classroom. Computers in Human Behavior, 70, 251-260.

Yılmaz, R. M., Reisoğlu, I., Topu, F. B., Karakuş, T., ve Göktaş, Y. (2015). The development of a criteria list for the selection of $3 \mathrm{~d}$ virtual worlds to design an educational environment. Croatian Journal of Education: Hrvatski časopis za odgoj i obrazovanje, 17(4), 1037-1069.

Yllmaz, T. K., ve Cagiltay, K. (2016). Designing and developing game-like learning experience in virtual worlds: Challenges and design decisions of novice instructional designers. Contemporary Educational Technology, 7(3), 206-222.

Zajda, J. (2018). Effective Constructivist Pedagogy for Quality Learning in Schools. Educational Practice and Theory, 40(1), 67-80. 


\section{Extended Abstract}

\section{Introduction}

Ensuring inclusive, equitable quality education and promoting lifelong learning opportunities for everyone is among goals set by the United Nations 2030 agenda for sustainable development. Some educational authorities argue that one means by which that goal can be reached is by using constructivist approach in teaching and curricula. This approach is used combined with other teaching methodologies. When seeking to improve the effectiveness and efficiency of education by using constructivism combined with collaboration, it is crucial to form groups while keeping in mind the set educational goals. In addition to improvement of effectiveness and efficiency, this methodology also contributes to better interaction and socialization of participants.

When this methodology is applied to internet based learning, the result is an enriched learning environment, in terms of communication and interaction. In addition, when different technologies are utilized in internet based education, they show different results regarding the sense of social presence. To get users to be active in the system, the learning environments need to be designed to resemble the real world as much as possible. Resemblance to the real world also improves the sense of social presence. In particular, changing avatars according to user preferences, the amount of interaction and the $3 \mathrm{D}$ voice technologies are making users experience 3D digital environments more similar to the real world. Browser based distance education gives a low sense of social presence. To improve that, and to get more effective and efficient results in education, the solution is to use $3 \mathrm{D}$ digital systems with online education.

The aim of this research is to develop a 3D virtual learning environment that supports collaborative learning, to identify elements that facilitate and obstruct the use of such environments, and to present solutions for problems which appear during the use of such environments.

\section{Method}

The formative research method which was used in this study is the qualitative research. The main aim is to develop a 3D virtual learning environment, starting from reviewing the literature, then, creating paper prototypes and educational framework. Then, all these were to be examined by specialists before proceeding to the next phase - creating the above mentioned environment. In the process of development of 3D virtual environment "OpenSim" was used. In the "virtual campus" which has been developed there are orientation site, education sites and entertainment sites. Orientation site is a place where the instructions are found for users, where they learn to adapt to the environment. Entertainment sites contain social and sports areas. On this site the users can have access to different fun applications, they can change the look of their avatars, and socialize with other users. On the education sites users will find brainstorming tools, presentation tools, communication board, office tools, whiteboards and similar application. Participants were 56 senior students who were at the time studying in the Computer Education and Instructional Technology department at a university located in Ankara. In the implementation process, participants were given "Task List" and they were asked to perform tasks. The implementation process was based on collaborative learning where 10 groups of 5 students were formed, whilst the 11th group had 6 participants. 
The tools used in the study were: Interview Form and Learning Environment Survey (LES). In this period, after the tools which exist in the environment collected data, the participants were asked to fill in the LES form. At the end of the survey, every group was interviewed for around 2.5 hours (not individually but as a group), 49 out of total number of participants. After obtaining all data, it was analyzed and coding scheme was set up by using cross-validation for reliability, under titles "facilitating the use of environment" or "obstructing the use of environment".

\section{Results}

The data were analyzed and accordingly the results were shown in following topics: "accessibility and communication", "usability", "education environment" and "virtual environments".

Elements that facilitate the accessibility and communication are: convenience of Internet-based use, installation manual is available, options to fly/teleport/run, detailed internal maps, abundance communication tools. Elements obstructing the accessibility and communication are: the IP address was dynamic, lack of manual for tablet, users' hardware was inadequate, users were not able access group rooms directly, system was not checking nonactive participants.

Elements that facilitate the usability are: simple and understandable design that can be learned and remembered. Elements obstructing the usability are: lack of password change panel, lack of privacy settings, starting point not easily identifiable, design problems of architectural structures in the system, day/night concepts have been found to change frequently.

Elements that facilitate the use as educational environment are: being alternative to formal education, increasing the focus on the lesson, flexibility to organize their time, convenience of lecture and project presentation tools, accessibility from any place, the useful educational tools. Elements obstructing the use as educational environment are: minor limitations of the educational tools, courses were not recorded, lack of shared cloud folder, lack of confidentiality and data security.

Elements that facilitate the use as a social environment are: sense of reality, learning about similar systems, and the existence of the manual, and previous experience of using similar systems. Elements obstructing the use as social environment are: sense of game-play, lack of FAQ panel at orientation.

\section{Discussion}

The results show that 3D virtual world which was created increased the motivation of participants and sense of social presence. We also should not forget that it enables flexibility of time and place and that it can be an alternative to traditional education. The freedom regarding the time comes from options of synchronized and unsynchronized education. The problems users found with the system can be easily solved, and the limitations of the system eliminated.

Future research can be made for example to compare traditional education with 3D virtual education by using quasi-experimental method; the research can be repeated with participants who will not have known each other previously. 
Also, future research can put into practice theoretical knowledge about psycho-motor skills, to apply it in fields such as vocational training, physical education and physical therapy practices. Studies can be also made in fields that use psychomotor abilities such as vocational training, physical education and physical therapy, in terms of putting theoretical knowledge into practice. 